\title{
TRP Channels in the Focus of Trigeminal Nociceptor Sensitization Contributing to Primary Headaches
}

\author{
Mária Dux ${ }^{1, * \mathbb{D}}$, Judit Rosta ${ }^{1}$ and Karl Messlinger ${ }^{2}$ \\ 1 Department of Physiology, University of Szeged, Dóm tér 10, H-6720 Szeged, Hungary; \\ tothne.rosta.judit.maria@med.u-szeged.hu \\ 2 Institute of Physiology and Pathophysiology, Friedrich-Alexander-University Erlangen-Nürnberg, \\ Universitätsstr. 17, D-91054 Erlangen, Germany; karl.messlinger@fau.de \\ * Correspondence: dux.maria@med.u-szeged.hu; Tel.: +36-62-545-374; Fax: +36-62-545-842
}

Received: 12 December 2019; Accepted: 2 January 2020; Published: 4 January 2020

\begin{abstract}
Pain in trigeminal areas is driven by nociceptive trigeminal afferents. Transduction molecules, among them the nonspecific cation channels transient receptor potential vanilloid 1 (TRPV1) and ankyrin 1 (TRPA1), which are activated by endogenous and exogenous ligands, are expressed by a significant population of trigeminal nociceptors innervating meningeal tissues. Many of these nociceptors also contain vasoactive neuropeptides such as calcitonin gene-related peptide (CGRP) and substance P. Release of neuropeptides and other functional properties are frequently examined using the cell bodies of trigeminal neurons as models of their sensory endings. Pathophysiological conditions cause phosphorylation, increased expression and trafficking of transient receptor potential (TRP) channels, neuropeptides and other mediators, which accelerate activation of nociceptive pathways. Since nociceptor activation may be a significant pathophysiological mechanism involved in both peripheral and central sensitization of the trigeminal nociceptive pathway, its contribution to the pathophysiology of primary headaches is more than likely. Metabolic disorders and medication-induced painful states are frequently associated with TRP receptor activation and may increase the risk for primary headaches.
\end{abstract}

Keywords: transient receptor potential vanilloid 1 ; transient receptor potential ankyrin 1 ; calcitonin gene-related peptide; primary headaches; trigeminal system; nociception

\section{Anatomical Basis of Headache Generation}

Primary headaches such as tension-type headache, migraine or trigemino-autonomic headaches are clinically well characterized, however, despite intense basic and clinical research, their origin remains still largely in the dark. In this contribution we ask whether sensitization of nociceptors may contribute to the generation of primary headaches [1] and how transduction channels of the transient receptor potential (TRP) type, which are typically expressed in nociceptors [2], are involved in the expected sensitizing mechanisms. Trigeminal nociceptors are primary afferents originating in the trigeminal ganglion, which is located in the Meckel's cave, a cavern on the floor of the middle cranial fossa. The trigeminal ganglion houses the somata of the primary afferent neurons and gives rise to three large cranial nerves containing mainly the peripheral axons of pseudo-unipolar primary afferent neurons, the ophthalmic (V1), the maxillary (V2), and the mandibular (V3) nerve. Like all other nociceptors, the trigeminal nociceptors consist of small primary sensory neurons with unmyelinated Cand thinly myelinated $\mathrm{A} \delta$-fibers, the central terminals of which run through the trigeminal nerve, enter the pontine brainstem and synapse on neurons in the spinal trigeminal nucleus (STN). The STN is also called trigemino-cervical brainstem complex, because it passes into the upper cervical segments without clear structural and functional boundary [3,4]. 
It is generally held that physiological pain results from activation of nociceptors innervating peripheral tissues, whereas pathophysiological pain may originate from more central sites of the nociceptive pathways. The question whether primary headaches belong to one of these categories is unsolved but most researchers may agree that trigeminal nociceptors are involved in the generation of headaches $[1,5]$. It is also widely accepted that nociceptors involved in headache generation innervate the meninges, although a contribution of nociceptors innervating tissues outside the head and the neck seems likely (see below). The cranial meninges consist of a delicate inner layer, the pia mater covering the entire cortical surface, and a tough outer layer bordering the skull, and the dura mater, which forms also the wall of the cranial sinuses. Between dura and pia mater, the cobweb-like arachnoidea lines the subarachnoidal space filled with cerebrospinal fluid. All three trigeminal partitions (V1-V3) participate in innervating the meninges, in the occipital region complemented by cervical afferents from segments C1-C3. In addition, the meninges are densely innervated also by postganglionic sympathetic fibers and sparsely by parasympathetic fibers originating in the cranial ganglia [4].

\section{Morphology and Role of Meningeal Nociceptors in Headache Generation}

The well-known classical intraoperative experiments performed by the groups of Harold Wolff and Wilder Penfield influenced our understanding of headache generation significantly until recently [6,7]. They observed that headache-like sensations could be elicited from arterial vessels of the dura mater, dural sinuses and large cerebral arteries, whereas the pia mater was entirely painless, regardless which noxious stimuli (mechanical, thermal or chemical) were used to stimulate these structures. There was a discrepancy with morphological data for a long time, since not only dural but also pial arteries were found to be innervated by thin peptidergic nerve fibers $[8,9]$, which are regarded as nociceptive (see below). This discrepancy has been solved in recent years, since a French group of neurosurgeons has collected conclusive data showing that stimulation of pial arterial structures can well cause painful sensations [10]. In addition to intracranial structures, Wolff's group reported long ago that also some extracranial arteries like the temporal artery can be sources for headache sensations [11], which is interesting in the light of new morphological findings of a collateral innervation of intra- and extracranial afferents $[12,13]$.

How are meningeal C- and A $\delta$-nociceptors characterized morphologically? Like other nociceptors they form so-called free nerve endings, which in ultrastructural dimensions are sensory axons, frequently in form of small Remak bundles, i.e., several axons embedded in a more or less continuous sheath of Schwann cells $[8,14]$. In the course of the sensory endings innervating peripheral tissues the Schwann cells show gaps, free areas, where the axolemma has direct contact to the surrounding tissue, which justifies the term "free" nerve ending (Figure 1A). It is obvious that these free areas are the sites for neuropeptide release into the surrounding and the sites where the axon exhibits transduction molecules and is sensitive to environmental noxious stimuli [8]. The accompanying Schwann cells seem to have also important functions, which may include signaling between axon and Schwann cell. Assuming that the size and shape of the free axonal areas is variable and can be regulated by the Schwann cell, it may be speculated that an increase in these gaps can increase the sensitivity of the nociceptive fiber. Recently it has been reported that specialized glial cells associated with unmyelinated nociceptive nerve fibers in the skin act even as primary transducers, since they show mechanosensitive properties and transmit the nociceptive information to the nerve endings [15]. The above morphological characteristics of free nerve endings have been reported in several tissues such as articular ligaments [16,17], skin [18], teeth [19] and meninges [14,20]; though it is not yet clear if they characterize specifically nociceptors, because thermoreceptive nerve fibers form also free nerve endings. Thus, it is possible that the morphology of free nerve endings does not provide any modality-specific characteristics, so that it is rather the equipment with membrane-bound receptor molecules that determines the modality (see below). 

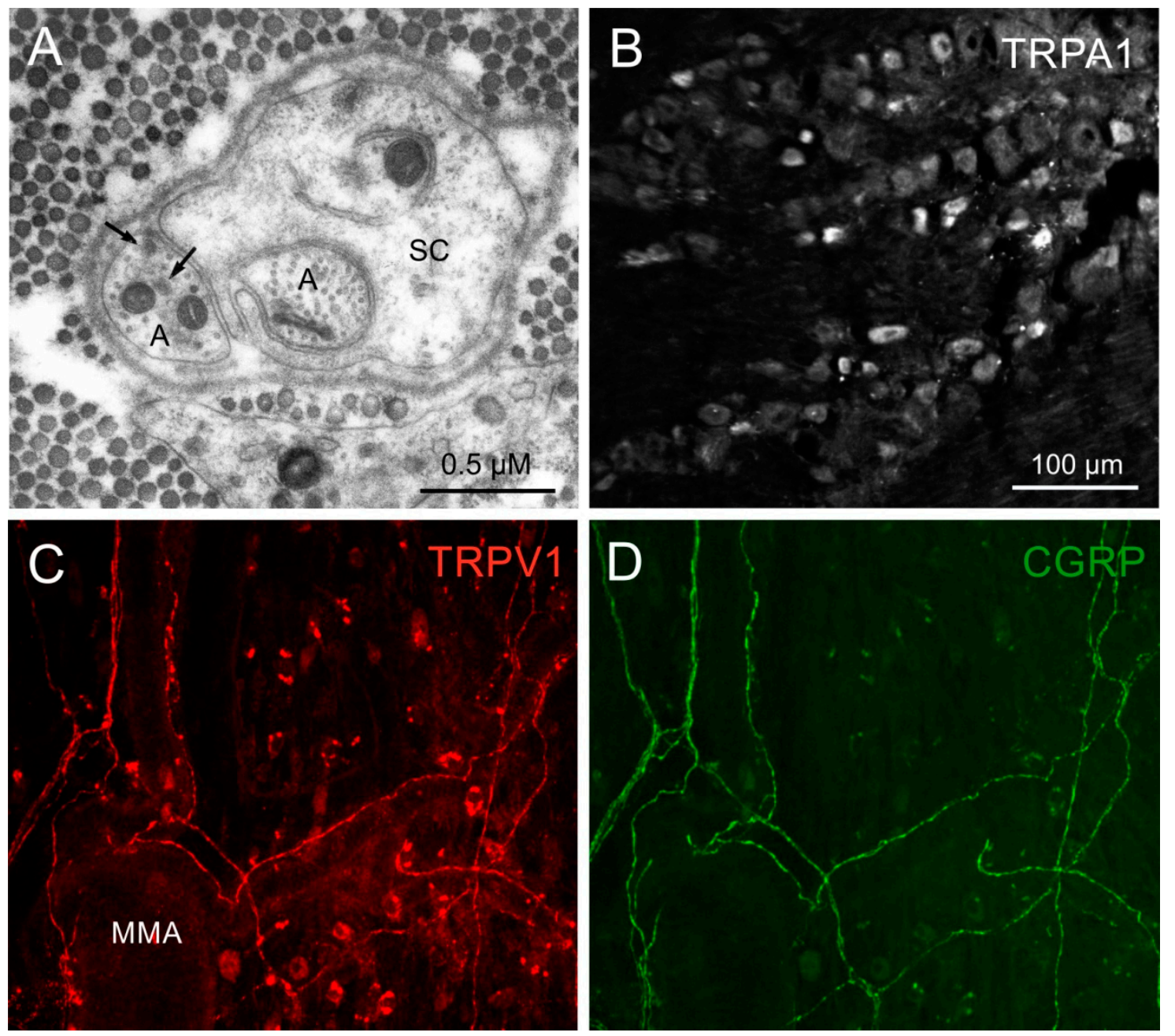

Figure 1. Ultrastructural characteristics of meningeal nociceptors. (A) Electron micrograph of a cross-sectioned small peripheral nerve fiber bundle in rat dura mater. Two sensory axons (A) are fully or partly wrapped by a Schwann cell (SC). The left axon contains two mitochondria and some dense-core vesicles (arrows), which most likely contain neuropeptides. The not covered axon membrane exposed to the surrounding (consisting mainly of collagen fibers) is probably an area of sensory transduction and neuropeptide release (see Figure 2). (B) Immunohistochemical staining of rat trigeminal ganglion for TRPA1. TRPA1-immunoreactive neurons are preferably small or middle-sized. (C-D) Double immunohistochemical staining for TRPV1 and calcitonin gene-related peptide (CGRP) in rat dura mater. Regarding the network of thin afferent fibers accompanying the middle meningeal artery (MMA) and its branches, TRPV1 and CGRP immunofluorescence are nearly completely co-localized.

The question if, and in which way, the activity of meningeal nociceptors determines the intensity of headaches is a matter of speculation. Meningeal nociceptors are certainly highly active when the dura mater is lesioned or inflamed, like in meningitis, since inflammatory mediators are very effective in driving primary and secondary trigeminal activity [21,22]. On the other hand, primary headaches like migraine and cluster headache can be extremely intense but we have no information about the level of primary afferent activity in these states. Following experimental cortical spreading depression (CSD) in rodents, which is regarded as an animal model of the aura phase followed by migraine attacks, i.e., a "natural" model of migraine generation, the meningeal C-fiber activity is remarkably low [23]. Therefore, it seems to be rather a matter of central sensitization that decides upon the intensity of headaches (see below). It may also be that the convergent afferent input from different tissues to the second order neurons in the spinal trigeminal nucleus (trigemino-cervical complex) is most 
important for the character and the intensity of headaches [24]. For example, strong afferent input from pericranial muscles and neck muscles is possibly not generating headaches unless there is additional meningeal afferent input. In a rat model of meningeal nociception, local anesthesia of neck muscles dramatically reduced the activity of spinal trigeminal neurons with convergent afferent input from the meninges [25].

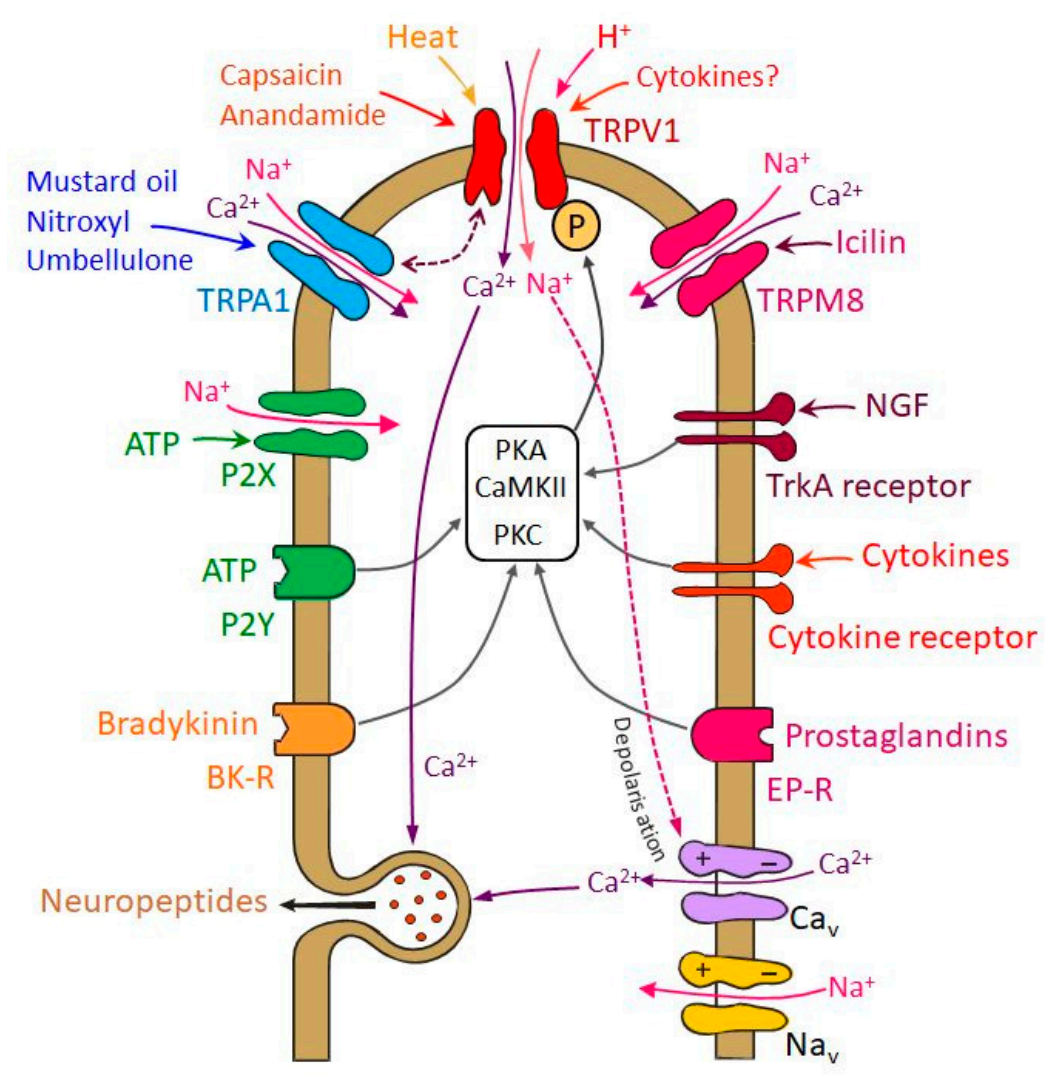

Figure 2. Scheme depicting important transduction processes in the nociceptive terminal. Transient receptor potential channels TRPV1, TRPA1 and TRPM8 may partly be co-expressed in the same terminals. TRPV1 is opened by noxious heat, whereas activation of TRPA1 and TRPM8 is facilitated under cold conditions. All TRP channels are also gated by specific endogenous and environmental substances. Opening of these transduction channels is followed by local cation inflow causing depolarization of the terminal, which can additionally activate voltage-gated cation channels inducing exocytosis of neuropeptides $\left(\mathrm{Ca}_{\mathrm{V}}\right)$ and generate action potentials $\left(\mathrm{Na}_{\mathrm{V}}\right)$. The TRP channels (here TRPV1 as an example) can be sensitized by phosphorylation $(\mathrm{P})$ through several protein kinases (protein kinase $\mathrm{A}$, PKA; protein kinase C, PKC; calcium calmodulin kinase II, CaMK II) induced by a variety of G-protein coupled receptors (purinergic receptors, P2Y; bradykinin receptors, BK-R; prostaglandin receptors, EP-R) or tyrosine kinase associated receptors (tyrosine kinase A, TrkA; cytokine receptors). TRP receptors can probably interact (double arrow between TRPV1 and TRPA1), thereby causing possibly both cross-sensitization and -desensitization.

\section{The Trigeminal Ganglion Neuron as a Model for Its Peripheral and Central Terminals}

Due to their small diameters, peripheral and central terminals of C- and A $\delta$-fibers are not accessible for several essential methods in neuroscience. For example, immunofluorescent intracellular or membrane-bound molecules associated with C-fibers can be visualized with confocal imaging in transparent tissues such as the rodent dura mater (Figure 1C,D) but quantifying immunofluorescence is not reliable in these tissues. Extracellular single fiber recordings can be performed in meningeal tissues with some special techniques like the tracking method [26,27] but measuring membrane potentials or currents with micropipettes is virtually impossible. Therefore molecular and neurophysiological 
properties of meningeal afferents are frequently studied by imaging and recording from trigeminal ganglion neurons in situ, isolated ganglia or in cell culture $[26,28,29]$. In these cases the soma of the neuron is regarded as a model of its endings, which is justified in that intracellular and membrane-bound molecules produced in the cell body are delivered via axonal transport to the peripheral and central terminals, where transduction and neurotransmission take place. Nevertheless this concept should be taken with caution, because molecules can be modified or assembled to functional units only in the terminals (for example the calcitonin gene-related peptide, CGRP, receptor complex) and some molecules may be transported unilaterally towards the periphery or the central nervous system (for example brain-derived neurotrophic factor, BDNF). Based on this concept different experimental approaches can be applied:

\subsection{Immunohistochemistry}

The trigeminal ganglion has been examined with this technique to detect neuropeptides such as substance P and calcitonin gene-related peptide (CGRP), long before TRP channels have been cloned and characterized. Probably the earliest immunohistochemical stainings, shortly after a similar study about dorsal root ganglia had been published [30], showed $40 \%$ of rat trigeminal ganglion with CGRPand $20 \%$ with substance P-immunoreactivity with nearly $100 \%$ co-localization [31]. In the human trigeminal ganglion nearly half of the neurons was found to be CGRP immunoreactive [32]. Significant proportions of trigeminal ganglion neurons show immunoreactivity for the transient receptor potential channels vanilloid 1 (TRPV1) and ankyrin 1 (TRPA1) (Figure 1B). In a comprehensive study on human trigeminal ganglia the number of neurons with co-localization of CGRP and TRPV1 was dependent on the age of the individuals with $61 \%$ in newborn and 35\% in adults [33]. Expression of TRPV1 and neuropeptides seem to be closely related in pathological states, e.g., in inferior alveolar nerve lesion [34].

\subsection{Neuropeptide Release}

Trigeminal ganglia in situ or cultivated trigeminal ganglion cells from rodents are frequently used to measure the release of substances following stimulation with noxious agents that target TRPV1 and TRPA1 receptors [35,36]. Particularly quantification of CGRP release from trigeminal ganglia or trigeminal cell cultures induced by capsaicin is regarded as a parameter for trigeminal activation and sensitization $[37,38]$. CGRP release from trigeminal ganglia has also been used to quantify the effect of antinociceptive substances like non-steroidal anti-inflammatory drugs and to analyze the mode of their actions [39]. The release studies are confounded by the fact that the trigeminal ganglion is wrapped by a double layer of dura mater, which prevents the direct access of stimulating substances and may hinder the diffusion of released substances into the bath solution.

\subsection{Electrophysiological Recordings}

In intact animals the trigeminal ganglia can be accessed by recording electrodes pushed through the cerebral cortex. Using this method, reliable extracellular recordings can be made, while the location of receptive fields indicates the innervation territories of trigeminal neurons. Threshold lowering, increase in activity upon suprathreshold stimulation and expansion of receptive fields are indicating nociceptor sensitization [28].

\subsection{Calcium Imaging}

Finally, trigeminal ganglion cell cultures have frequently been used to study the molecular properties of neurons and responses to endogenous and environmental mediators using calcium imaging [36,37]. Agonists and antagonists specifically targeting TRP receptor channels are employed to find out the role of TRPs in the neuronal activation [40]. For example, the irritating effect of carvacrol and eugenol, ingredients of spices, were shown by calcium imaging to result from activation of TRPA1 [41]. Using DiI tracing, dental primary afferents have been shown responding to hyperosmotic 
stimuli with calcium transients, which were dependent on transient receptor potential melastatin 8 (TRPM8) activation [42].

\section{Expression of TRPV1 and TRPA1 and Co-Expression with Neuropeptides}

Receptor channels of the TRP family are expressed by significant proportions of trigeminal ganglion neurons $[43,44]$. TRP receptors form unspecific cation transduction channels in peripheral sensory endings and may also be involved in synaptic transmission at the central terminals [45].

Nociceptive afferents can be grouped into peptidergic neurons, most of which express vanilloid-sensitive transient receptor potential (TRPV1) channels, and non-peptidergic neurons, which are characterized by their isolectin B4 (IB4) binding. The first group is sensitive to nerve growth factor (NGF), while the second group is sensitive to glial cell-line derived neurotrophic factor (GDNF) during the development [46,47]. Apart from the expression of TRPV1, the two groups may be different in some minor physiological functions like neurotransmitter release [48]. However, this grouping seems not very clear-cut, since immunostaining has shown considerable overlap of TRPV1 and IB4 binding in primary afferent neurons of rat and mouse, particularly in the rat trigeminal ganglion [49]. Interestingly, the authors found 70\% of CGRP-immunoreactive neurons colocalized with TRPV1 immunoreactivity (see Figure 1C,D), which was significantly more compared to dorsal root ganglia and may be one explanation for the dominant role of CGRP as a signaling neuropeptide in the trigeminal system.

TRPV1 receptor channels are activated by pungent substances like capsaicin or resiniferatoxin, noxious heat, acids $(\mathrm{pH}<5.3)$, and different endogenous compounds including membrane-derived lipid metabolites like anandamide (Figure 2) [50]. TRPA1 receptor channels, which are highly colocalized with TRPV1 in trigeminal neurons, are activated by irritants like mustard oil and cannabinoids [51-53]. TRPA1 can also be activated by volatile substances such as umbellulone of the "headache tree" [54]. Its functional role in trigeminal nociception is controversial, because there is experimental evidence for a cooperative effect with TRPV1 in meningeal afferents [55] but also for a dual nociceptive-antinociceptive effect when recordings were made from spinal trigeminal neurons [56], as discussed below in more detail (Figure 2). Another member of the TRP receptor family implicated in the migraine pathophysiology is the TRPM8 that is a cold-sensitive channel activated also by natural and synthetic "cooling" agents, such as menthol and icilin (Figure 2). Some of the TRPM8-positive cells may also express TRPV1 or CGRP, but a substantial fraction is not labeled by nociceptive markers $[57,58]$.

\section{Functional Significance of Mediator Trafficking to Afferent Fiber Terminals}

As discussed above, trigeminal ganglia or isolated ganglion neurons are frequently used as models of their peripheral (sometimes also central) terminals assuming that most of the signal molecules expressed in the cell bodies are delivered by axonal transport to the periphery and/or into the central nervous system. By this way neuropeptides are transported into the peripheral terminals, where they can be released upon stimulation by calcium-dependent exocytosis and induce symptoms of neurogenic inflammation [59,60]; likewise in the central terminals they act as neuromodulators contributing to synaptic transmission $[61,62]$. Receptors are transported as well and integrated into the terminal cell membrane, for example serotonin 1B/D (5-HT1B/D) receptors, the activation of which counteracts neuropeptide and glutamate release and hence eripheral transduction and central neurotransmission $[63,64]$.

However, morphological and functional findings suggest that some of the receptor proteins are unidirectionally transported to a large extent. For example, CGRP receptor components have been found by confocal immunohistochemistry co-localized with axonal markers only in the central but not in the peripheral processes of rat trigeminal neurons, which may indicate that they are unilaterally delivered to the central terminals [65], although other data do not support this assumption [66]. As all these molecules are produced in the cell body, every mechanism interacting with their gene expression has consequences for the peripheral and central functions of these neurons. For example, CGRP receptors integrated into the presynaptic membrane of central trigeminal terminals may be activated 
by CGRP released from adjacent terminals of other trigeminal afferents to facilitate neurotransmitter release and synaptic transmission [67,68]. Another example is BDNF, the expression of which is enhanced by CGRP in cultured trigeminal neurons [69]. BDNF and other neurotrophic factors have been found to stimulate the expression of TRPV1 and to increase the sensitivity of TRPV1 and TRPA1 receptor channels in dorsal root ganglion neurons [70] as well as TRPV1-mediated CGRP release from trigeminal ganglion neurons [47]. BDNF is not specific for the somatosensory system but is also important for other, e.g., cardiovascular functions [71]. Interestingly, however, BDNF produced by trigeminal afferents is delivered by axonal transport into the trigeminal nucleus, where it can be released from central presynaptic terminals and may act on pre- and postsynaptic tyrosine kinase (TrkB) receptors to facilitate nociceptive transmission [72]. Thus, substances acting on neurons within the trigeminal ganglion, which is outside the blood-brain barrier, can have considerable impact on the peripheral and central functions of nociceptive transduction and transmission. This mode of action is clearly relevant regarding the recent discussion about big molecules like monoclonal antibodies, which reach the central nervous system only at very low concentrations [73] and are therefore assumed to act mainly outside the blood-brain barrier inhibiting CGRP signaling and reducing trigeminal functions involved in migraine [74], as reviewed elsewhere [75,76].

\section{Signals Sensitizing Trigeminal Nociceptors-Involvement and Interaction of TRP Receptors}

A lower threshold for neuronal activation, indicated as lowered pain threshold of facial areas one day prior to a migraine attack, can be observed in migraineurs compared with healthy controls suggesting an altered condition of neuronal excitability [77]. This may occur as result of peripheral and/or central sensitization of the trigeminal nociceptive pathway. During the initial phase of a migraine attack the occurrence of throbbing pain may be considered as the consequence of an increased sensitivity of peripheral trigeminal neurons that innervate the meninges [21]. Physical activities increasing intracranial pressure generally worsen these symptoms. Previously innocuous stimuli on the facial skin may be uncomfortable or even painful during a migraine attack. This cutaneous allodynia is thought developing through the sensitization of second-order neurons in the spinal trigeminal nucleus, which receive convergent input from meningeal tissues as well as from the facial skin [78,79]. Sensitization of primary sensory neurons may occur through repeated or sustained activation that may have also a long-lasting effect on the function of the second-order neurons in the trigeminal nociceptive pathway leading to an increased susceptibility even in the absence of the peripheral sensitizing agent.

Multiple changes in TRPV1 and TRPA1 receptor function may be involved in sensitization of trigeminal nociceptors (Figure 2). Phosphorylation of the receptors by protein kinase A (PKA) or protein kinase $\mathrm{C}$ (PKC) decreases their activation threshold, leading to an increased open probability of the ion channels $[80,81]$. Besides this short-term regulation, intermediate and long-term regulatory mechanisms also lead to the sensitization of TRP receptors. Phosphorylation of TRPV1 protein stored in vesicles may accelerate their exocytosis and the insertion of functional TRPV1 receptors into the cell membrane (see below) [82]. Increasing the amount of TRPV1 or TRPA1 receptors on the surface membrane contributes to nociceptor sensitization on an intermediate time scale. Effects increasing receptor protein expression may have long-lasting effect on nociceptor sensitivity $[83,84]$.

Activation of TRPV1 and TRPA1 receptor channels by pungent plant compounds like capsaicin or substances from mustard and garlic as well as environmental irritants such as formaldehyde and acrolein [85] go along with inward sodium currents depolarizing the sensory endings and calcium currents inducing neuropeptide release (Figure 2) [38], which leads to arterial vasodilatation and increased blood flow [86-88]. One might assume that the released neuropeptides contribute to nociceptor sensitization. However, CGRP is not activating nociceptors directly and does therefore not cause pain but seems to contribute only to pain generation after the nociceptive system has already been sensitized, for example by glycerol trinitrate (GTN), which mimics the action of nitric oxide (NO), as it was demonstrated by CGRP injection into facial skin in GTN pretreated rats [89]. 
Neurogenic inflammation of the meningeal tissue and CSD are pathophysiological conditions considered as endogenous mechanisms initiating cascades of events that may activate and/or sensitize nociceptors in the meningeal tissue leading to hypersensitivity and allodynia. In animal models chemical irritation of the dura mater was found to activate and sensitize meningeal nociceptors $[59,90]$. Proinflammatory substances play a significant role in these sensitizing processes (Figure 2). Initial release of neuropeptides from activated nociceptors may potentiate the secretion of proinflammatory mediators, e.g., by degranulating dural mast cells [91,92]. Electrophysiological recordings showed that capsaicin-induced neuronal responses are enhanced by prostaglandine E2 and prostacyclin through the activation of cAMP-dependent protein kinase A (PKA) and protein kinase C (PKC) pathways $[80,93]$. PKC activation and consequent phosphorylation seem to be also mechanisms of ATP- and bradykinin-induced sensitization of nociceptors [94,95].

Chronic migraine patients show elevated levels of NGF in their cerebrospinal fluid [96]. Under experimental conditions expression of NGF mRNA and release of NGF can be enhanced by sensory neuropeptides like CGRP [97]. Elevated NGF levels, similarly to insulin and insulin-like growth factor 1 (IGF-1), activate phosphatidylinositol-3-kinase that may lead to phosphorylation of the TRP receptors through calcium/calmodulin-dependent protein kinase II (CaMKII) and PKC [98,99].

Activation of the tyrosine kinase receptor A (TrkA) by NGF, insulin or IGF-1 initiates a cascade of events leading to phosphorylation of TRPV1 that is located in intracellular vesicles. This increases the amount of functional TRPV1 in the cell membrane by increasing its trafficking [100]. Recent experiments showed upregulation of TRPA1 mRNA in trigeminal ganglion neurons innervating the dura mater after chronic exposure of rats to an atmosphere containing the TRPA1 agonist acrolein [101]. Interestingly, an increase in TRPV1 protein content but not TRPV1 mRNA was measured following treatment of trigeminal ganglion neurons with NGF mediated by the mitogen-activated protein kinase pathway [102].

Calcium inflow into the nociceptors may also lead to desensitization of TRPV1 via calcium/calmodulin-dependent protein phosphatase 2B (calcineurin) and $\beta$-arrestin-2 [103,104]. Similar mechanisms may be assumed for TRPA1. Thus, sensitization and desensitization counteract and may be more or less balanced depending on the state of TRP activation (Figure 2). The situation is even more complicated in neurons expressing both TRPV1 and TRPA1 [52]. There is evidence that these two receptor channels interact in that TRPA1 activation limits TRPV1-mediated current but also desensitization due to the TRPA1-mediated current [105]. Therefore, it seems possible that the interactions of both channels can both increase or decrease trigeminal nociceptor activity, depending on the strength of their activation. Extracellular recordings from meningeal afferents revealed a mainly cooperative effect between TRPV1 and TRPA1 confirmed in TRPV1-deleted mice [55]. Activation of TRPA1 receptor channels increased the activation threshold and did not cause propagated action potentials unless TRPV1 was present. These effects may be further modulated in afferent second order neurons. In a rat model of meningeal nociception, recordings from neurons in the spinal trigeminal nucleus with meningeal afferent input indicated that individual neurons may be activated or inhibited by the TRPA1 agonist nitroxyl (HNO, see below) [56]. Thus, the effects of TRPA1 agonists may depend on the site of action (peripheral vs. central terminals) and the functional characteristics of higher order neurons.

Single nucleotide polymorphisms associated with the susceptibility for migraine have been identified in genes coding for TRPV1 and TRPV3 but the pathophysiological relations with known migraine mechanisms are yet unclear [106]. Besides TRPV1 and TRPA1, TRPM8 receptors are expressed in TG neurons (Figure 2). TRPM8 is interesting, because genome-wide association studies showed that it may be implicated in migraine $[107,108]$, i.e., more specifically, single-nucleotide variants near or within the TRPM8 gene resulting in reduced TRPM8 expression are associated with reduced risk for migraine [109]. TRPM8 has been identified as a sensor for environmental cold [57] and low body temperature [110] but experimental work on trigeminal nociceptive functions is contradictory. The TRPM8 agonist icilin applied onto the rat cranial dura mater induced cutaneous facial and hind paw 
allodynia that was attenuated by systemic pretreatment with a TRPM8 antagonist [111,112]. On the contrary, TRPM8 activation reversed an increase in facial sensitivity to heat induced by meningeal inflammation, and in a trigeminal ganglion cell assay TRPM8 activation inhibited TRPV1 effects [101]. Thus TRPM8 activation by exogenous agonists may both aggravate and alleviate headache-related behaviors, possibly depending on the activation of other pro-nociceptive receptors of meningeal afferents [58].

In this context it is very interesting that both TRPV1 and TRPM8 receptor channels are differently involved in the regulation of body temperature [109]. While TRPV1 activation causes a decrease, TRPM8 activation causes an increase in body temperature; the basal activity of both receptor channels counteracts excesses of the body temperature, thereby contributing to homeostasis. It is intriguing, although evolutionary fitting, that single-nucleotide variants causing reduced TRPM8 expression, which is associated with a higher risk for migraine, are more frequently found in populations that live in warmer geographic areas [113].

Ten years ago already, several TRPV1 antagonists have entered clinical trials, including ABT-102, SB-705498, AMG-517, MK2295 and GRC-6211 [114], however, the major setback in the development of TRPV1 antagonists for the treatment of chronic pain was an elevation of the body temperature. Attempts to develop TRPV1 antagonists without causing hyperthermia are in the focus of recent pharmacological research [115].

\section{Sensitization of Trigeminal Nociceptors Following Cortical Spreading Depression}

Cortical spreading depression (CSD) is characterized by a slowly propagating wave of depolarization followed by suppression of cortical activity, a complex event, which induces dramatic changes in neural and vascular functions. CSD has been implicated in the pathophysiology of migraine, derived from neuroimaging studies which showed changes in cortical blood flow (propagating with similar velocity as the experimental CSD) during the visual aura phase of migraine [116,117]. Since aura in most cases precedes the onset of headache, it was hypothesized that CSD may lead to the activation of meningeal nociceptors [118]. Although animal models provide support for this hypothesis, its relationship to migraine attacks is still under debate. CSD may stimulate dural nociceptors either by axon collaterals innervating both the pia mater and the dura mater [119] or by the direct diffusion of molecules such as potassium ions, hydrogen ions or glutamate released during CSD [120,121]. CSD may also increase the production of reactive oxygen species in the cortex, in meningeal tissues and also in the trigeminal ganglion [122]. Low extracellular $\mathrm{pH}$ or oxidizing agents may directly activate TRPA1 and TRPV1 channels through modification of cysteine (Figure 2); they excite trigeminal nociceptors and induce the release of CGRP from trigeminal terminals to promote sensitization of trigeminal neurons [123]. Recently it was shown that CGRP-binding monoclonal antibodies can prevent the development of central sensitization and cutaneous allodynia elicited by CSD [124].

In vivo two-photon imaging of anesthetized mice revealed changes in the morphology of macrophages and motility of dendritic cells in the meninges in relation to CSD [125]. During CSD, meningeal macrophages changed their shape and migration of dendritic cells stopped, which was considered as changes in meningeal immune cell function signalizing to the TRPV1 expressing meningeal nociceptors. These observations are consistent with earlier findings on meningeal immune cells, where CSD was observed causing degranulation of mast cells and potentiating the activation of dural nociceptors [126].

\section{Role of Metabolic States in Trigeminal Sensitization}

Population-based studies indicate that migraine can be associated with metabolic disorders. Obesity, insulin resistance and diabetes mellitus are conditions that are linked to the primary headache migraine. These conditions may enhance the frequency and severity of headache attacks and they may increase the risk for migraine $[127,128]$. Our knowledge about sensitization of trigeminal nociceptors in metabolic disorders is based on studies in experimental animals. 
Recent experimental observations indicated that in rats, high-fat high-sucrose (HFHS) diet increased fasting blood glucose and insulin concentrations as well as levels of the circulating proinflammatory cytokines interleukin-1 $\beta$ (IL-1 $\beta$ ) and interleukin-6 (IL-6). HFHS diet-induced obesity was associated with enhanced basal and stimulated CGRP release from meningeal nociceptors. Both TRPV1 and TRPA1 receptor sensitivity to the specific stimulatory agents capsaicin and acrolein, respectively, was increased. Stimulation of TRPV1 and TRPA1 receptors resulted also in a significantly augmented vasodilatory response in meningeal blood vessels of obese animals $[129,130]$.

Experimental results indicate that migraine pathophysiology and the conditions leading to the excess of body fat overlap in several aspects. Adipose tissue produces bioactive molecules, which serve as regulators of metabolism and also modulate immune functions [131,132]. Since HFHS diet of experimental animals sensitizes TRP receptor function without obvious changes in density or distribution of TRPV1-immunoreactive afferents of the dura mater and TRPA1 protein expression in the trigeminal ganglion, sensitization of the TRP receptors is more likely the consequence of the release of proinflammatory agents produced by the adipose tissue. IL-1 $\beta$ may directly modify the gating properties of TRP channels for noxious stimuli in primary sensory neurons but leave the transport of TRP channels to the plasma membrane unaffected [133].

Streptozotocin injection destroying insulin secreting cells of pancreatic Langerhans islets reduced the number of TRPV1-immunoreactive nerve fibers of the dura mater in rats [134]. Impairment of trigeminal nociceptors develops slowly; loss of TRPV1-mediated CGRP release and the lack of meningeal vasodilatation upon TRPV1 stimulation cannot be observed shortly after the induction of diabetes, which may be explained by the slow decrease in neuronal peptide levels after treatment with streptozotocin. In the rat trigeminal ganglion, CGRP markedly declined only five weeks after the induction of diabetes [135].

Despite the impaired function of chemosensitive trigeminal afferents, clinical observations indicate that diabetic patients suffer more frequently from headaches than non-diabetics [127]. It was hypothesized that dysfunction of the afferents may contribute to the enhanced incidence of headaches in diabetics due to a limited elimination of tissue metabolites and inflammatory mediators from meningeal tissues.

Another endocrine disorder, hypothyroidism, seems to have a bidirectional association with migraine. Common genetic and immune mechanisms are considered as underlying pathophysiological processes [136]. TRP receptor ion channels may function as possible targets for proinflammatory cytokine effects leading to increased incidence of migraine attacks in hypothyroid patients.

\section{Intraganglionic Mechanisms Involved in Nociceptor Sensitization}

Migraine attacks can be triggered by the activation of trigeminal afferents innervating extracranial tissues. Inhaled environmental irritants stimulating TRPA1 receptors of the nasal mucosa, allergic rhinitis, acute sinusitis and temporomandibular joint disorder are risk factors for migraine [101,137]. Cross-excitation within the trigeminal ganglion may explain why activation of one branch of the trigeminal nerve can promote cellular changes that result in sensitization within the entire ganglion and lead to the generation of headaches.

CGRP can be released not only from the peripheral and central terminals of activated trigeminal neurons but also from the cell body [138]. CGRP released within the ganglion may facilitate spreading of information throughout the whole ganglion [139]. Within the trigeminal ganglion both neurons and satellite glial cells can express CGRP receptor components, and accordingly they serve as targets of CGRP effects. In rats $32 \%$ of neurons in the trigeminal ganglion express both calcitonin-like receptor (CLR) and receptor activity modifying protein 1 (RAMP1) receptor components indicating the formation of functional CGRP receptors [65]. Neurons expressing CGRP receptor components are frequently found in close vicinity to CGRP containing neurons, which enable cross-talk between them. The neurotransmitters glutamate and ATP have also been implicated in the communication within the 
trigeminal ganglion. Experimental studies have demonstrated the expression of excitatory glutamate receptors and ATP receptors in sensory neurons [140,141].

Besides direct transmission of information from one neuron to the other, activation of satellite glial cells may provide an additional indirect mechanism for the sensitization of other neurons initially not involved in the nociceptive process. Glial cells activated by the initial transmitter release from trigeminal neurons may release inflammatory molecules leading to sensitization of neurons [142]. Glutamate release from satellite glial cells cultured from the trigeminal ganglion was also reported as intraganglionic signaling mechanism [143].

The TRPV1 receptor agonist endovanilloid/endocannabinoid anadamide and other endogenous lipid metabolites or inhaled irritants activating trigeminal TRPA1 receptors are well-known mechanisms leading to activation of some trigeminal neurons [54,144]; their intraganglionic effect may probably play a significant role in the process of cross-sensitization within the trigeminal ganglion.

\section{Sensitization Processes within the Trigeminovascular System}

A subpopulation of trigeminal neurons innervating the dura mater express the proteinase-activated receptor-2 (PAR-2) that may be a target for proteolytic enzymes, e.g., tryptase released from activated mast cells [145]. Cleavage exposes tethered ligand domains that bind to and activate cleaved receptors. Since meningeal mast cells are targets for neuropeptide actions, release of CGRP or substance P from meningeal afferents may degranulate mast cells leading to the release of mast cell tryptase and consequent PAR-2 activation. Experimental observations indicate that activation of PAR-2 induces sensitization of the TRPV1 receptor in trigeminal afferents, elicits CGRP release and enhances meningeal blood flow upon stimulation the TRPV1 receptor with its specific agonist capsaicin [146]. Mast cell tryptase activating the PAR-2 receptor may sensitize not only TRPV1 but also TRPA1 receptors of trigeminal afferents. Cleavage of PAR-2 may activate phopholipase $C$, which unlocks TRP receptors from phosphatidylinositol-4,5-bisphosphate inhibition [147]. Since also mast cells possess PAR-2 receptors, a mutual activation of mast cells through the released tryptase may initiate a self-triggering mechanism of mast cells resulting in an amplification of the primary nociceptive response and probably also the sensitivity of the second-order neurons in the nociceptive pathway [148].

Hydrogen sulfide $\left(\mathrm{H}_{2} \mathrm{~S}\right)$ and $\mathrm{NO}$, members of the gasotransmitter family, are involved in the regulation of a great variety of physiological functions, including cardiovascular functions, nociception and inflammation $[149,150]$. A substantial body of evidence indicates that $\mathrm{H}_{2} \mathrm{~S}$ increases the firing rate of trigeminal ganglion neurons by acting on TRP receptors [56,151]. $\mathrm{H}_{2} \mathrm{~S}$ is synthesized from cysteine through several enzymatic pathways. The $\mathrm{H}_{2} \mathrm{~S}$ producing enzyme cystathionine $\beta$-synthase (CBS) is abundantly expressed in the trigeminal ganglion of rats [152] and under inflammatory conditions CBS expression may be upregulated at both protein and mRNA levels [153].

Recent studies reported that $\mathrm{H}_{2} \mathrm{~S}$ produced in peripheral tissue may interact with $\mathrm{NO}$ and results in generation of polysulfides $[154,155]$ or $\mathrm{HNO}$, a protonated, one electron-reduced derivative of NO [156]. Polysulfides and HNO are activators of TRPA1 receptors. In the dura mater HNO production and its effect on TRPA1 receptors seems to be the main mechanism of $\mathrm{H}_{2} \mathrm{~S}$-induced vasodilatation and CGRP release [157]. In the trigeminal ganglion of rats, CBS immunoreactivity was partly colocalized with TRPA1 in small trigeminal neurons [152]. Continuous generation of HNO in the meningeal tissue and its CGRP releasing effect through the activation of TRPA1 seems to be also a significant vasodilatory component maintaining basal meningeal blood flow [157].

\section{Medication-Induced Trigeminal Nociception and Pain}

Epidemiological studies indicate that in patients suffering from primary headaches the progressive increase in the use of acute medication increases the number of headache days per months leading to medication overuse headache $(\mathrm{MOH})$. All specific migraine and pain medications seem to have the capacity to cause $\mathrm{MOH}$ [158]. Pathophysiological studies in animal models have suggested that central sensitization of the trigeminal nociceptive pathway may function as a basis for MOH. Central 
sensitization induced by chronic application of drugs like triptans, paracetamol or opiates seems to underlie the pathogenesis of $\mathrm{MOH}$.

A recent study reports the lack of association between the polymorphisms of TRPV1, TRPA1 and TRPM8 ion channels and MOH in patients [159]. In different animal models of $\mathrm{MOH}$, similar metabolic changes in the trigeminovascular system were observed; increase in CGRP expression and decrease in 5-HT1B/D receptor expression [160]. Clinical studies in $\mathrm{MOH}$ patients have shown that 5-HT levels decrease, which may subsequently reduce the inhibitory effect mediated by the 5-HT1B/1D receptors of trigeminal sensory neurons on sensory neuropeptide release [161]. Increased CGRP release upon TRPV1 or TRPA1 activation induced by their specific agonists may be involved in the sensitization process.

Drugs used for other purposes than headache therapy may alter the sensitivity of nociceptors leading to uncomfortable or painful sensations upon administration. The $\alpha 1$-adrenoceptor agonist phenylephrine used at high concentrations as a mydriatic agent and for the treatment of nasal congestion may induce local burning sensation or headache as adverse side effect [36]. Recent experiments revealed that high concentrations of phenylephrine activate trigeminal neurons in rodent models of trigeminal nociception. This activation induces calcium inflow and consequent CGRP release from trigeminal neurons innervating the meningeal tissues. As a neurovascular consequence of the peptide release, increases in meningeal blood flow were recorded. Activation of trigeminal nociceptors was mainly the result of the activation of TRPV1 receptor channels by phenylephrine. The contribution of TRPA1 receptor activation was excluded, since pretreatment of the dura mater with the TRPV1 receptor antagonist abolished the phenylephrine-induced CGRP release and meningeal blood flow increase, while the TRPA1 receptor antagonist had no effect on it. Results obtained in trigeminal neurons of TRPV1-deficient animals supported this observation. Phenylephrine-induced calcium transients and CGRP release were abolished in trigeminal ganglion neurons of TRPV1-deficient animals [36].

A potent anthracycline-type antitumor agent, adriamycin, is used in the treatment of various malignancies [162]. As serious side effects, impairments in sensory nerve functions were reported, which may also significantly contribute to the cardiomyopathy developing in some patients $[163,164]$. Recent findings revealed multiple but selective impairments of receptor functions in the trigeminovascular system after adriamycin treatment. Adriamycin affected the nociceptor channels TRPV1 and TRPA1 and also the CGRP receptors of meningeal arteries. While the impairment of chemosensitive nociceptors was clearly indicated by the reduced TRPV1 content of trigeminal ganglia of adriamycin-treated animals, in the dura mater whole mount preparations the density and distribution of TRPV1-immunoreactive afferents were not significantly changed. Measurements of CGRP release in an ex vivo dura mater preparation revealed an altered dynamic of peptide release upon repeated stimulations of TRPV1 and TRPA1 receptors. The first application of an agonist of TRPV1 or TRPA1 receptor induced a significantly higher increase in CGRP release in adriamycin-treated animals compared to control animals, while further applications failed to increase the release [165]. Although headache is not a major problem among patients treated with adriamycin, and to our knowledge no clinical studies indicated increased incidence of headache in this population, the impaired trigeminal nociceptor function coupled with impaired vasodilator capacity of meningeal blood vessels may be an important mechanism contributing to pain sensation.

\section{Synopsis: Relevance of TRPV1 and TRPA1 in Primary Headaches}

Clinical observations and animal studies provide evidence for a central role of trigeminal afferents in the mechanisms of primary headaches $[5,166]$. A significant population of trigeminal afferents expressing the nociceptive ion channels TRPV1 and TRPA1 are peptidergic. They contribute not only to the transmission of the nociceptive information towards the central nervous system but their neuropeptide content released from their peripheral and central terminals and also from their cell body upon activation may have a significant modulatory effect on long-term pain perception. Different peptides (CGRP, substance P or pituitary adenylate cyclase-activating peptide) possessing vasodilatory 
function have been identified in trigeminal neurons $[167,168]$. Being the most abundant peptide in the trigeminal system, expressed by approximately $40 \%$ of neurons, CGRP has gained major attention in clinical and experimental studies on the pathomechanisms of primary headaches. Reducing the release of CGRP, blocking its receptor or binding CGRP with humanized anti-CGRP antibodies seem to be effective in the treatment or prevention of migraine attacks $[76,169]$. CGRP released within the trigeminal ganglion may sensitize other neurons directly or by acting on satellite glial cells. According to the currently accepted view, meningeal arterial vasodilatation induced by CGRP does not play a causative role in primary headaches [5]. CGRP-induced meningeal vasodilatation may still have a beneficial effect, e.g., by removing inflammatory mediators from the meningeal tissue and preventing or reducing the activation and/or sensitization of the nociceptive pathway. Release of CGRP from trigeminal nociceptors and initiation of processes leading to peripheral and central sensitization of the nociceptive pathway can be induced by different endogenous and exogenous agents acting on TRPV1 or TRPA1 receptors. The important role of TRP receptors in the activation and sensitization of trigeminal nociceptors make them possible targets for drug developments that counteract the channel opening or the expression of the channels, thereby reducing CGRP release from trigeminal afferents. Removing the key mediator CGRP may interrupt the vicious circle leading to increased susceptibility for headache attacks.

Given that TRPV1 receptor channels play a major role in nociceptive transduction, the question was if they are also involved in the generation of primary headaches. Therefore, animal models of headache have been employed, which admittedly provided inconsistent results. Systemic administration of the TRPV1 antagonist SB-705498 suppressed responses to stimulation of the dura mater and the facial skin and reversed the sensitization of second order neurons in the spinal trigeminal nucleus of cats induced by inflammatory compounds [170]. The authors concluded that inhibiting TRPV1 may be useful to treat inflammatory trigeminovascular pain but expressed their skepticism regarding primary headaches. In two other animal studies in the rat the TRPV1 antagonists JNJ-38893777 and JNJ-17203212 suppressed the generation of the immediate early gene c-fos, provoked by intracisternal application of inflammatory mediators, and attenuated the CGRP release into the external jugular vein following injection of capsaicin into the carotid artery. The authors concluded that TRPV1 may play a role in the pathophysiological mechanisms relevant to migraine [171]. In contrast, the TRPV1 antagonist A-993610 had no significant effect on the activity of rat spinal trigeminal neurons evoked by electrical stimulation of the dura mater, did not block neurogenic vasodilatation of dural arteries and did not cause any change in the CSD response induced by pin prick. Based on these results the authors concluded that blockade of TRPV1 receptor channels will gain no role in the treatment of acute migraine [172].

Some volatile agonists of TRPA1 are known to trigger headaches in sensitive persons. The best known example is the scent of the Californian "headache tree", Umbellularia california, the active compound of which, the monoterpene ketone umbellulone, was found to activate TRPA1 receptor channels expressed in HEK293 cells and trigeminal ganglion neurons and to cause nociceptive behavior in wild-type but not TRPA1-deficient mice [54,173]. Another plant is fewerfew (Tanacetum parthenium), which has been used for centuries to treat headache and other pains. Its major constituent, parthenolide, has also been found to stimulate TRPA1 receptor channels but behaves as a partial agonist, which preferably desensitizes trigeminal neurons [174]. Curcumin, the active principle of turmeric root (Curcuma longa) also activates and subsequently desensitizes TRPA1 ion channels [175]. Regarding TRPV1, partial agonism was found for two major components of Evodia rutaecarpa, evodiamine and rutaecarpine, from which the first one reduced capsaicin- and proton-evoked currents in TRPV1-expressing HEK293 cells [176].

Extracts of the butterbur plant (Petasites hybridus) with the main component isopetasin have long been used as preventives for migraine [177]. Isopetasin has been shown to induce calcium signals and inward currents in rodent trigeminal ganglion neurons and CGRP release from mouse dorsal spinal cord via activation of TRPA1 receptor channels, while pre-exposure to isopetasin attenuated responses 
to the TRPA1 agonist allyl isothiocyanate and the TRPV1 agonist capsaicin in these preparations. Repeated systemic administration of isopetasin attenuated also mouse facial rubbing evoked by local allyl isothiocyanate or capsaicin. The authors concluded that activation of TRPA1 channels by isopetasin and excitation of neuropeptidergic trigeminal neurons causes heterologous neuronal desensitization, which may account for the anti-migraine effect of petasites extracts [178]. Thus, regarding the above discussion, the role of TRP receptor channels in headache generation seems to be ambiguous, and it may be a matter of the balance of sensitizing-desensitizing mechanisms if a TRP agonist is preferentially triggering or preventing headaches.

Funding: This work was supported by research grants GINOP-2.3.2-15-2016-00034 and K119597 project of the Hungarian National Research, Development and Innovation Office, by the University of Szeged Open Access Fund (Grant number: 4514) and by the Alexander von Humboldt Foundation, Research Group Linkage Program.

Conflicts of Interest: The authors declare no conflict of interest.

\section{References}

1. Bernstein, C.; Burstein, R. Sensitization of the Trigeminovascular Pathway: Perspective and Implications to Migraine Pathophysiology. J. Clin. Neurol. 2012, 8, 89-99. [CrossRef] [PubMed]

2. Mickle, A.D.; Shepherd, A.J.; Mohapatra, D.P. Sensory TRP Channels: The Key Transducers of Nociception and Pain. Prog. Mol. Biol. Transl. Sci. 2015, 131, 73-118. [PubMed]

3. Bolay, H.; Messlinger, K.; Dux, M.; Akcali, D. Anatomy of headache. In Pathophysiology of Headaches, 1st ed.; Ashina, M., Geppetti, P., Eds.; Springer International Publishing: Cham, Switzerland, 2015; pp. 1-29. ISBN 978-3-319-15621-7.

4. Messlinger, K.; Dux, M. Functional anatomy of trigeminovascular pain. In Neurobiological Basis of Migraine; Dalkara, T., Moskowitz, M., Eds.; John Wiley \& Sons Inc.: Hoboken, USA, 2017; pp. 3-29. ISBN 978-1-118-96719-5.

5. Goadsby, P.J.; Holland, P.R.; Martins-Oliveira, M.; Hoffmann, J.; Schankin, C.; Akerman, S. Pathophysiology of Migraine: A Disorder of Sensory Processing. Physiol. Rev. 2017, 97, 553-622. [CrossRef] [PubMed]

6. Penfield, W.; McNaughton, M. Dural headache and innervation of the dura mater. Arch. Neurol. Psychiatr. 1940, 44, 43-75. [CrossRef]

7. Ray, B.S.; Wolff, H.G. Experimental studies on headache: Pain sensitive structures of the head and their significance in headache. Arch. Surg. 1940, 1, 813-856. [CrossRef]

8. Messlinger, K.; Hanesch, U.; Baumgärtel, M.; Trost, B.; Schmidt, R.F. Innervation of the dura mater encephali of cat and rat: Ultrastructure and calcitonin gene-related peptide-like and substance P-like immunoreactivity. Anat. Embryol. 1993, 188, 219-237. [CrossRef]

9. Fricke, B.; von Düring, M.; Andres, K.H. Topography and immunocytochemical characterization of nerve fibers in the leptomeningeal compartments of the rat. A light- and electron-microscopical study. Cell Tissue Res. 1997, 287, 11-22. [CrossRef]

10. Fontaine, D.; Almairac, F.; Santucci, S.; Fernandez, C.; Dallel, R.; Pallud, J.; Lanteri-Minet, M. Dural and pial pain-sensitive structures in humans: New inputs from awake craniotomies. Brain 2018, 141, 1040-1048. [CrossRef]

11. Graham, J.R.; Wolff, H.G. Mechanism of migraine headache and action of ergotamine tartrate. Arch. Neurol Psychiatr. 1938, 39, 737-763. [CrossRef]

12. Schueler, M.; Messlinger, K.; Dux, M.; Neuhuber, W.L.; De Col, R. Extracranial projections of meningeal afferents and their impact on meningeal nociception and headache. Pain 2013, 154, 1622-1631. [CrossRef]

13. Zhao, J.; Levy, D. The sensory innervation of the calvarial periosteum is nociceptive and contributes to headache-like behavior. Pain 2014, 155, 1392-1400. [CrossRef] [PubMed]

14. Andres, K.H.; von Düring, M.; Muszynski, K.; Schmidt, R.F. Nerve fibres and their terminals of the dura mater encephali of the rat. Anat. Embryol. 1987, 175, 289-301. [CrossRef] [PubMed]

15. Abdo, H.; Calvo-Enrique, L.; Lopez, J.M.; Song, J.; Zhang, M.-D.; Usoskin, D.; El Manira, A.; Adameyko, I.; Hjerling-Leffler, J.; Ernfors, P. Specialized cutaneous Schwann cells initiate pain sensation. Science 2019, 365, 695-699. [CrossRef] [PubMed] 
16. Heppelmann, B.; Messlinger, K.; Neiss, W.F.; Schmidt, R.F. Ultrastructural three-dimensional reconstruction of group III and group IV sensory nerve endings (free nerve endings) in the knee joint capsule of the cat: Evidence for multiple receptive sites. J. Comp. Neurol. 1990, 292, 103-116. [CrossRef]

17. Messlinger, K. Functional Morphology of Nociceptive and Other Fine Sensory Endings (Free Nerve Endings) in Different Tissues. In The Polymodal Receptor - a Gateway to Pathological Pain; Elsevier: Amsterdam, Netherlands, 1996; pp. 273-298.

18. Munger, B.L.; Ide, C. The structure and function of cutaneous sensory receptors. Arch. Histol. Cytol. 1988, 51, 1-34. [CrossRef]

19. Byers, M.R. Sensory innervation of periodontal ligament of rat molars consists of unencapsulated Ruffini-like mechanoreceptors and free nerve endings. J. Comp. Neurol. 1985, 231, 500-518. [CrossRef]

20. Von Düring, M.; Andres, K.H. Sensory nerve fiber terminals in the arachnoid granulations of non-human primates. Neurosci. Lett. 1991, 127, 121-124. [CrossRef]

21. Strassman, A.M.; Raymond, S.A.; Burstein, R. Sensitization of meningeal sensory neurons and the origin of headaches. Nature 1996, 384, 560-564. [CrossRef]

22. Schepelmann, K.; Ebersberger, A.; Pawlak, M.; Oppmann, M.; Messlinger, K. Response properties of trigeminal brain stem neurons with input from dura mater encephali in the rat. Neuroscience 1999, 90, 543-554. [CrossRef]

23. Zhang, X.; Levy, D.; Noseda, R.; Kainz, V.; Jakubowski, M.; Burstein, R. Activation of meningeal nociceptors by cortical spreading depression: Implications for migraine with aura. J. Neurosci. 2010, 30, 8807-8814. [CrossRef]

24. Olesen, J.; Burstein, R.; Ashina, M.; Tfelt-Hansen, P. Origin of pain in migraine: Evidence for peripheral sensitisation. Lancet Neurol. 2009, 8, 679-690. [CrossRef]

25. Roch, M.; Messlinger, K.; Kulchitsky, V.; Tichonovich, O.; Azev, O.; Koulchitsky, S. Ongoing activity in trigeminal wide-dynamic range neurons is driven from the periphery. Neuroscience 2007, 150, 681-691. [CrossRef] [PubMed]

26. Cabanes, C.; Viana, F.; Belmonte, C. Differential thermosensitivity of sensory neurons in the guinea pig trigeminal ganglion. J. Neurophysiol. 2003, 90, 2219-2231. [CrossRef]

27. De Col, R.; Messlinger, K.; Carr, R.W. Repetitive activity slows axonal conduction velocity and concomitantly increases mechanical activation threshold in single axons of the rat cranial dura. J. Physiol. 2012, 590, 725-736. [CrossRef] [PubMed]

28. Levy, D.; Burstein, R.; Strassman, A.M. Calcitonin gene-related peptide does not excite or sensitize meningeal nociceptors: Implications for the pathophysiology of migraine. Ann. Neurol. 2005, 58, 698-705. [CrossRef] [PubMed]

29. Yan, J.; Wei, X.; Bischoff, C.; Edelmayer, R.M.; Dussor, G. pH-evoked dural afferent signaling is mediated by ASIC3 and is sensitized by mast cell mediators. Headache 2013, 53, 1250-1261. [CrossRef]

30. Wiesenfeld-Hallin, Z.; Hökfelt, T.; Lundberg, J.M.; Forssmann, W.G.; Reinecke, M.; Tschopp, F.A.; Fischer, J.A. Immunoreactive calcitonin gene-related peptide and substance P coexist in sensory neurons to the spinal cord and interact in spinal behavioral responses of the rat. Neurosci. Lett. 1984, 52, 199-204. [CrossRef]

31. Lee, Y.; Kawai, Y.; Shiosaka, S.; Takami, K.; Kiyama, H.; Hillyard, C.J.; Girgis, S.; MacIntyre, I.; Emson, P.C.; Tohyama, M. Coexistence of calcitonin gene-related peptide and substance P-like peptide in single cells of the trigeminal ganglion of the rat: Immunohistochemical analysis. Brain Res. 1985, 330, 194-196. [CrossRef]

32. Eftekhari, S.; Salvatore, C.A.; Calamari, A.; Kane, S.A.; Tajti, J.; Edvinsson, L. Differential distribution of calcitonin gene-related peptide and its receptor components in the human trigeminal ganglion. Neuroscience 2010, 169, 683-696. [CrossRef]

33. Quartu, M.; Serra, M.P.; Boi, M.; Poddighe, L.; Picci, C.; Demontis, R.; Del Fiacco, M. TRPV1 receptor in the human trigeminal ganglion and spinal nucleus: Immunohistochemical localization and comparison with the neuropeptides CGRP and SP. J. Anat. 2016, 229, 755-767. [CrossRef]

34. Martins, D.O.; Santos, F.M.; Britto, L.R.G.; Lemos, J.B.D.; Chacur, M. Neurochemical effects of photobiostimulation in the trigeminal ganglion after inferior alveolar nerve injury. J. Biol. Regul. Homeost. Agents 2017, 31, 147-152.

35. Kageneck, C.; Nixdorf-Bergweiler, B.E.; Messlinger, K.; Fischer, M.J. Release of CGRP from mouse brainstem slices indicates central inhibitory effect of triptans and kynurenate. J. Headache Pain 2014, 15, 7. [CrossRef] [PubMed] 
36. Dux, M.; Babes, A.; Manchen, J.; Sertel-Nakajima, J.; Vogler, B.; Schramm, J.; Messlinger, K. High-dose phenylephrine increases meningeal blood flow through TRPV1 receptor activation and release of calcitonin gene-related peptide. Eur. J. Pain 2019. [CrossRef] [PubMed]

37. Thalakoti, S.; Patil, V.V.; Damodaram, S.; Vause, C.V.; Langford, L.E.; Freeman, S.E.; Durham, P.L. Neuron-glia signaling in trigeminal ganglion: Implications for migraine pathology. Headache 2007, 47, 1008-1023, discussion 24-25. [CrossRef] [PubMed]

38. Meng, J.; Ovsepian, S.V.; Wang, J.; Pickering, M.; Sasse, A.; Aoki, K.R.; Lawrence, G.W.; Dolly, J.O. Activation of TRPV1 mediates calcitonin gene-related peptide release, which excites trigeminal sensory neurons and is attenuated by a retargeted botulinum toxin with anti-nociceptive potential. J. Neurosci. 2009, 29, 4981-4992. [CrossRef]

39. Vellani, V.; Moschetti, G.; Franchi, S.; Giacomoni, C.; Sacerdote, P.; Amodeo, G. Effects of NSAIDs on the Release of Calcitonin Gene-Related Peptide and Prostaglandin E2 from Rat Trigeminal Ganglia. Mediat. Inflamm. 2017, 2017, 9547056. [CrossRef]

40. Lehmann, R.; Schöbel, N.; Hatt, H.; van Thriel, C. The involvement of TRP channels in sensory irritation: A mechanistic approach toward a better understanding of the biological effects of local irritants. Arch. Toxicol. 2016, 90, 1399-1413. [CrossRef]

41. Klein, A.H.; Joe, C.L.; Davoodi, A.; Takechi, K.; Carstens, M.I.; Carstens, E. Eugenol and carvacrol excite first- and second-order trigeminal neurons and enhance their heat-evoked responses. Neuroscience 2014, 271, 45-55. [CrossRef]

42. Lee, P.R.; Lee, J.Y.; Kim, H.B.; Lee, J.H.; Oh, S.B. TRPM8 Mediates Hyperosmotic Stimuli-Induced Nociception in Dental Afferents. J. Dent. Res. 2019, 99, 107-114. [CrossRef]

43. Huang, D.; Li, S.; Dhaka, A.; Story, G.M.; Cao, Y.-Q. Expression of the transient receptor potential channels TRPV1, TRPA1 and TRPM8 in mouse trigeminal primary afferent neurons innervating the dura. Mol. Pain 2012, 8, 66. [CrossRef]

44. Geppetti, P.; Benemei, S.; De Cesaris, F. CGRP receptors and TRP channels in migraine. J. Headache Pain 2015, 16, A21. [CrossRef] [PubMed]

45. Raisinghani, M.; Zhong, L.; Jeffry, J.A.; Bishnoi, M.; Pabbidi, R.M.; Pimentel, F.; Cao, D.-S.; Evans, M.S.; Premkumar, L.S. Activation characteristics of transient receptor potential ankyrin 1 and its role in nociception. Am. J. Physiol. Cell Physiol. 2011, 301, C587-C600. [CrossRef] [PubMed]

46. Vedder, H.; Affolter, H.U.; Otten, U. Nerve growth factor (NGF) regulates tachykinin gene expression and biosynthesis in rat sensory neurons during early postnatal development. Neuropeptides 1993, 24, 351-357. [CrossRef]

47. Price, T.J.; Louria, M.D.; Candelario-Soto, D.; Dussor, G.O.; Jeske, N.A.; Patwardhan, A.M.; Diogenes, A.; Trott, A.A.; Hargreaves, K.M.; Flores, C.M. Treatment of trigeminal ganglion neurons in vitro with NGF, GDNF or BDNF: Effects on neuronal survival, neurochemical properties and TRPV1-mediated neuropeptide secretion. BMC Neurosci. 2005, 6, 4. [CrossRef]

48. Matsuka, Y.; Edmonds, B.; Mitrirattanakul, S.; Schweizer, F.E.; Spigelman, I. Two types of neurotransmitter release patterns in isolectin B4-positive and negative trigeminal ganglion neurons. Neuroscience 2007, 144, 665-674. [CrossRef]

49. Price, T.J.; Flores, C.M. Critical evaluation of the colocalization between calcitonin gene-related peptide, substance $\mathrm{P}$, transient receptor potential vanilloid subfamily type 1 immunoreactivities, and isolectin B4 binding in primary afferent neurons of the rat and mouse. J. Pain 2007, 8, 263-272. [CrossRef]

50. Price, T.J.; Patwardhan, A.; Akopian, A.N.; Hargreaves, K.M.; Flores, C.M. Modulation of trigeminal sensory neuron activity by the dual cannabinoid-vanilloid agonists anandamide, $\mathrm{N}$-arachidonoyl-dopamine and arachidonyl-2-chloroethylamide. Br. J. Pharmacol. 2004, 141, 1118-1130. [CrossRef]

51. Jordt, S.-E.; Bautista, D.M.; Chuang, H.-H.; McKemy, D.D.; Zygmunt, P.M.; Högestätt, E.D.; Meng, I.D.; Julius, D. Mustard oils and cannabinoids excite sensory nerve fibres through the TRP channel ANKTM1. Nature 2004, 427, 260-265. [CrossRef]

52. Salas, M.M.; Hargreaves, K.M.; Akopian, A.N. TRPA1-mediated responses in trigeminal sensory neurons: Interaction between TRPA1 and TRPV1. Eur. J. Neurosci. 2009, 29, 1568-1578. [CrossRef]

53. Benemei, S.; De Cesaris, F.; Fusi, C.; Rossi, E.; Lupi, C.; Geppetti, P. TRPA1 and other TRP channels in migraine. J. Headache Pain 2013, 14, 71. [CrossRef] 
54. Nassini, R.; Materazzi, S.; Vriens, J.; Prenen, J.; Benemei, S.; De Siena, G.; la Marca, G.; Andrè, E.; Preti, D.; Avonto, C.; et al. The "headache tree" via umbellulone and TRPA1 activates the trigeminovascular system. Brain 2012, 135, 376-390. [CrossRef]

55. Denner, A.C.; Vogler, B.; Messlinger, K.; De Col, R. Role of transient receptor potential ankyrin 1 receptors in rodent models of meningeal nociception-Experiments in vitro. Eur. J. Pain 2017, 21, 843-854. [CrossRef] [PubMed]

56. Teicher, C.; De Col, R.; Messlinger, K. Hydrogen Sulfide Mediating both Excitatory and Inhibitory Effects in a Rat Model of Meningeal Nociception and Headache Generation. Front. Neurol. 2017, 8, 336. [CrossRef] [PubMed]

57. Bautista, D.M.; Siemens, J.; Glazer, J.M.; Tsuruda, P.R.; Basbaum, A.I.; Stucky, C.L.; Jordt, S.-E.; Julius, D. The menthol receptor TRPM8 is the principal detector of environmental cold. Nature 2007, 448, $204-208$. [CrossRef]

58. Dussor, G.; Cao, Y.-Q. TRPM8 and Migraine. Headache 2016, 56, 1406-1417. [CrossRef] [PubMed]

59. Moskowitz, M.A. Neurogenic inflammation in the pathophysiology and treatment of migraine. Neurology 1993, 43, S16-S20. [PubMed]

60. Williamson, D.J.; Hargreaves, R.J.; Hill, R.G.; Shepheard, S.L. Sumatriptan inhibits neurogenic vasodilation of dural blood vessels in the anaesthetized rat-intravital microscope studies. Cephalalgia 1997, 17, 525-531. [CrossRef] [PubMed]

61. Storer, R.J.; Akerman, S.; Goadsby, P.J. Calcitonin gene-related peptide (CGRP) modulates nociceptive trigeminovascular transmission in the cat. Br. J. Pharmacol. 2004, 142, 1171-1181. [CrossRef]

62. Coste, J.; Voisin, D.L.; Miraucourt, L.S.; Dallel, R.; Luccarini, P. Dorsal horn NK1-expressing neurons control windup of downstream trigeminal nociceptive neurons. Pain 2008, 137, 340-351. [CrossRef]

63. Hou, M.; Kanje, M.; Longmore, J.; Tajti, J.; Uddman, R.; Edvinsson, L. 5-HT(1B) and 5-HT(1D) receptors in the human trigeminal ganglion: Co-localization with calcitonin gene-related peptide, substance $P$ and nitric oxide synthase. Brain Res. 2001, 909, 112-120. [CrossRef]

64. Xiao, Y.; Richter, J.A.; Hurley, J.H. Release of glutamate and CGRP from trigeminal ganglion neurons: Role of calcium channels and 5-HT1 receptor signaling. Mol. Pain 2008, 4, 12. [CrossRef]

65. Lennerz, J.K.; Rühle, V.; Ceppa, E.P.; Neuhuber, W.L.; Bunnett, N.W.; Grady, E.F.; Messlinger, K. Calcitonin receptor-like receptor (CLR), receptor activity-modifying protein 1 (RAMP1), and calcitonin gene-related peptide (CGRP) immunoreactivity in the rat trigeminovascular system: Differences between peripheral and central CGRP receptor distribution. J. Comp. Neurol. 2008, 507, 1277-1299. [CrossRef]

66. Eftekhari, S.; Warfvinge, K.; Blixt, F.W.; Edvinsson, L. Differentiation of nerve fibers storing CGRP and CGRP receptors in the peripheral trigeminovascular system. J. Pain 2013, 14, 1289-1303. [CrossRef]

67. Takhshid, M.A.; Owji, A.A.; Panjehshahin, M.R. In vitro effects of adrenomedullin and calcitonin gene related peptide on the release of serotonin and amino acids from rat dorsal spinal cord. Neurosci. Lett. 2007, 420, 193-197. [CrossRef]

68. Edvinsson, J.C.A.; Warfvinge, K.; Krause, D.N.; Blixt, F.W.; Sheykhzade, M.; Edvinsson, L.; Haanes, K.A. C-fibers may modulate adjacent A $\delta$-fibers through axon-axon CGRP signaling at nodes of Ranvier in the trigeminal system. J. Headache Pain 2019, 20, 105. [CrossRef]

69. Buldyrev, I.; Tanner, N.M.; Hsieh, H.; Dodd, E.G.; Nguyen, L.T.; Balkowiec, A. Calcitonin gene-related peptide enhances release of native brain-derived neurotrophic factor from trigeminal ganglion neurons. $J$. Neurochem. 2006, 99, 1338-1350. [CrossRef]

70. Ciobanu, C.; Reid, G.; Babes, A. Acute and chronic effects of neurotrophic factors BDNF and GDNF on responses mediated by thermo-sensitive TRP channels in cultured rat dorsal root ganglion neurons. Brain Res. 2009, 1284, 54-67. [CrossRef]

71. Kermani, P.; Hempstead, B. BDNF Actions in the Cardiovascular System: Roles in Development, Adulthood and Response to Injury. Front. Physiol. 2019, 10, 455. [CrossRef]

72. Garraway, S.M.; Huie, J.R. Spinal Plasticity and Behavior: BDNF-Induced Neuromodulation in Uninjured and Injured Spinal Cord. Neural Plast. 2016, 2016, 9857201. [CrossRef]

73. Johnson, K.W.; Morin, S.M.; Wroblewski, V.J.; Johnson, M.P. Peripheral and central nervous system distribution of the CGRP neutralizing antibody [125I] galcanezumab in male rats. Cephalalgia 2019, 39, 1241-1248. [CrossRef]

74. Russo, A.F. Calcitonin Gene-Related Peptide (CGRP). Annu. Rev. Pharm. Toxicol. 2015, 55, 533-552. [CrossRef] 
75. DosSantos, M.F.; Holanda-Afonso, R.C.; Lima, R.L.; DaSilva, A.F.; Moura-Neto, V. The role of the blood-brain barrier in the development and treatment of migraine and other pain disorders. Front. Cell Neurosci. 2014, 8, 302. [CrossRef]

76. Edvinsson, L. CGRP receptor antagonists and antibodies against CGRP and its receptor in migraine treatment. Br. J. Clin. Pharmacol. 2015, 80, 193-199. [CrossRef]

77. Sand, T.; Zhitniy, N.; Nilsen, K.B.; Helde, G.; Hagen, K.; Stovner, L.J. Thermal pain thresholds are decreased in the migraine preattack phase. Eur. J. Neurol. 2008, 15, 1199-1205. [CrossRef]

78. Burstein, R.; Yarnitsky, D.; Goor-Aryeh, I.; Ransil, B.J.; Bajwa, Z.H. An association between migraine and cutaneous allodynia. Ann. Neurol. 2000, 47, 614-624. [CrossRef]

79. Lipton, R.B.; Bigal, M.E.; Ashina, S.; Burstein, R.; Silberstein, S.; Reed, M.L.; Serrano, D.; Stewart, W.F. American Migraine Prevalence Prevention Advisory Group Cutaneous allodynia in the migraine population. Ann. Neurol. 2008, 63, 148-158. [CrossRef]

80. Lopshire, J.C.; Nicol, G.D. The cAMP transduction cascade mediates the prostaglandin E2 enhancement of the capsaicin-elicited current in rat sensory neurons: Whole-cell and single-channel studies. J. Neurosci. 1998, 18, 6081-6092. [CrossRef]

81. Moriyama, T.; Higashi, T.; Togashi, K.; Iida, T.; Segi, E.; Sugimoto, Y.; Tominaga, T.; Narumiya, S.; Tominaga, M. Sensitization of TRPV1 by EP1 and IP reveals peripheral nociceptive mechanism of prostaglandins. Mol. Pain 2005, 1, 3. [CrossRef]

82. Morenilla-Palao, C.; Planells-Cases, R.; García-Sanz, N.; Ferrer-Montiel, A. Regulated exocytosis contributes to protein kinase C potentiation of vanilloid receptor activity. J. Biol. Chem. 2004, 279, 25665-25672. [CrossRef]

83. Tohda, C.; Sasaki, M.; Konemura, T.; Sasamura, T.; Itoh, M.; Kuraishi, Y. Axonal transport of VR1 capsaicin receptor mRNA in primary afferents and its participation in inflammation-induced increase in capsaicin sensitivity. J. Neurochem. 2001, 76, 1628-1635. [CrossRef]

84. Amaya, F.; Oh-hashi, K.; Naruse, Y.; Iijima, N.; Ueda, M.; Shimosato, G.; Tominaga, M.; Tanaka, Y.; Tanaka, M. Local inflammation increases vanilloid receptor 1 expression within distinct subgroups of DRG neurons. Brain Res. 2003, 963, 190-196. [CrossRef]

85. Kunkler, P.E.; Ballard, C.J.; Oxford, G.S.; Hurley, J.H. TRPA1 receptors mediate environmental irritant-induced meningeal vasodilatation. Pain 2011, 152, 38-44. [CrossRef]

86. Dux, M.; Sántha, P.; Jancsó, G. Capsaicin-sensitive neurogenic sensory vasodilatation in the dura mater of the rat. J. Physiol. 2003, 552, 859-867. [CrossRef]

87. Gupta, S.; Akerman, S.; van den Maagdenberg, A.M.J.M.; Saxena, P.R.; Goadsby, P.J.; van den Brink, A.M. Intravital microscopy on a closed cranial window in mice: A model to study trigeminovascular mechanisms involved in migraine. Cephalalgia 2006, 26, 1294-1303. [CrossRef]

88. Dux, M.; Will, C.; Eberhardt, M.; Fischer, M.J.M.; Messlinger, K. Stimulation of rat cranial dura mater with potassium chloride causes CGRP release into the cerebrospinal fluid and increases medullary blood flow. Neuropeptides 2017, 64, 61-68. [CrossRef]

89. Capuano, A.; Greco, M.C.; Navarra, P.; Tringali, G. Correlation between algogenic effects of calcitonin-gene-related peptide (CGRP) and activation of trigeminal vascular system, in an in vivo experimental model of nitroglycerin-induced sensitization. Eur. J. Pharmacol. 2014, 740, 97-102. [CrossRef]

90. Holzer, P. Local effector functions of capsaicin-sensitive sensory nerve endings: Involvement of tachykinins, calcitonin gene-related peptide and other neuropeptides. Neuroscience 1988, 24, 739-768. [CrossRef]

91. Levy, D.; Burstein, R.; Kainz, V.; Jakubowski, M.; Strassman, A.M. Mast cell degranulation activates a pain pathway underlying migraine headache. Pain 2007, 130, 166-176. [CrossRef]

92. Schwenger, N.; Dux, M.; de Col, R.; Carr, R.; Messlinger, K. Interaction of calcitonin gene-related peptide, nitric oxide and histamine release in neurogenic blood flow and afferent activation in the rat cranial dura mater. Cephalalgia 2007, 27, 481-491. [CrossRef]

93. Smith, J.A.; Davis, C.L.; Burgess, G.M. Prostaglandin E2-induced sensitization of bradykinin-evoked responses in rat dorsal root ganglion neurons is mediated by cAMP-dependent protein kinase A. Eur. J. Neurosci. 2000, 12, 3250-3258. [CrossRef]

94. Premkumar, L.S.; Ahern, G.P. Induction of vanilloid receptor channel activity by protein kinase C. Nature 2000, 408, 985-990. [CrossRef] 
95. Tominaga, M.; Wada, M.; Masu, M. Potentiation of capsaicin receptor activity by metabotropic ATP receptors as a possible mechanism for ATP-evoked pain and hyperalgesia. Proc. Natl. Acad. Sci. USA 2001, 98, 6951-6956. [CrossRef]

96. Sarchielli, P.; Mancini, M.L.; Floridi, A.; Coppola, F.; Rossi, C.; Nardi, K.; Acciarresi, M.; Pini, L.A.; Calabresi, P. Increased levels of neurotrophins are not specific for chronic migraine: Evidence from primary fibromyalgia syndrome. J. Pain 2007, 8, 737-745. [CrossRef] [PubMed]

97. Dallos, A.; Kiss, M.; Polyánka, H.; Dobozy, A.; Kemény, L.; Husz, S. Effects of the neuropeptides substance P, calcitonin gene-related peptide, vasoactive intestinal polypeptide and galanin on the production of nerve growth factor and inflammatory cytokines in cultured human keratinocytes. Neuropeptides 2006, 40, 251-263. [CrossRef]

98. Bonnington, J.K.; McNaughton, P.A. Signalling pathways involved in the sensitisation of mouse nociceptive neurones by nerve growth factor. J. Physiol. 2003, 551, 433-446. [CrossRef]

99. Van Buren, J.J.; Bhat, S.; Rotello, R.; Pauza, M.E.; Premkumar, L.S. Sensitization and translocation of TRPV1 by insulin and IGF-I. Mol. Pain 2005, 1, 17. [CrossRef] [PubMed]

100. Zhang, X.; Huang, J.; McNaughton, P.A. NGF rapidly increases membrane expression of TRPV1 heat-gated ion channels. EMBO J. 2005, 24, 4211-4223. [CrossRef]

101. Zhang, L.; Kunkler, P.E.; Knopp, K.L.; Oxford, G.S.; Hurley, J.H. Role of intraganglionic transmission in the trigeminovascular pathway. Mol. Pain 2019, 15. [CrossRef]

102. Ji, R.-R.; Samad, T.A.; Jin, S.-X.; Schmoll, R.; Woolf, C.J. p38 MAPK activation by NGF in primary sensory neurons after inflammation increases TRPV1 levels and maintains heat hyperalgesia. Neuron 2002, 36, 57-68. [CrossRef]

103. Por, E.D.; Samelson, B.K.; Belugin, S.; Akopian, A.N.; Scott, J.D.; Jeske, N.A. PP2B/calcineurin-mediated desensitization of TRPV1 does not require AKAP150. Biochem. J. 2010, 432, 549-556. [CrossRef]

104. Por, E.D.; Bierbower, S.M.; Berg, K.A.; Gomez, R.; Akopian, A.N.; Wetsel, W.C.; Jeske, N.A. $\beta$-Arrestin-2 desensitizes the transient receptor potential vanilloid 1 (TRPV1) channel. J. Biol. Chem. 2012, 287, 37552-37563. [CrossRef]

105. Masuoka, T.; Kudo, M.; Yamashita, Y.; Yoshida, J.; Imaizumi, N.; Muramatsu, I.; Nishio, M.; Ishibashi, T. TRPA1 Channels Modify TRPV1-Mediated Current Responses in Dorsal Root Ganglion Neurons. Front. Physiol. 2017, 8, 272. [CrossRef]

106. Carreño, O.; Corominas, R.; Fernández-Morales, J.; Camiña, M.; Sobrido, M.-J.; Fernández-Fernández, J.M.; Pozo-Rosich, P.; Cormand, B.; Macaya, A. SNP variants within the vanilloid TRPV1 and TRPV3 receptor genes are associated with migraine in the Spanish population. Am. J. Med. Genet. B Neuropsychiatr. Genet. 2012, 159B, 94-103. [CrossRef]

107. Chasman, D.I.; Schürks, M.; Anttila, V.; de Vries, B.; Schminke, U.; Launer, L.J.; Terwindt, G.M.; van den Maagdenberg, A.M.J.M.; Fendrich, K.; Völzke, H.; et al. Genome-wide association study reveals three susceptibility loci for common migraine in the general population. Nat. Genet. 2011, 43, 695-698. [CrossRef]

108. Freilinger, T.; Anttila, V.; de Vries, B.; Malik, R.; Kallela, M.; Terwindt, G.M.; Pozo-Rosich, P.; Winsvold, B.; Nyholt, D.R.; van Oosterhout, W.P.J.; et al. Genome-wide association analysis identifies susceptibility loci for migraine without aura. Nat. Genet. 2012, 44,777-782. [CrossRef]

109. Gavva, N.R.; Sandrock, R.; Arnold, G.E.; Davis, M.; Lamas, E.; Lindvay, C.; Li, C.-M.; Smith, B.; Backonja, M.; Gabriel, K.; et al. Reduced TRPM8 expression underpins reduced migraine risk and attenuated cold pain sensation in humans. Sci. Rep. 2019, 9, 19655. [CrossRef]

110. Almeida, M.C.; Hew-Butler, T.; Soriano, R.N.; Rao, S.; Wang, W.; Wang, J.; Tamayo, N.; Oliveira, D.L.; Nucci, T.B.; Aryal, P.; et al. Pharmacological blockade of the cold receptor TRPM8 attenuates autonomic and behavioral cold defenses and decreases deep body temperature. J. Neurosci. 2012, 32, 2086-2099. [CrossRef]

111. Burgos-Vega, C.C.; Ahn, D.D.-U.; Bischoff, C.; Wang, W.; Horne, D.; Wang, J.; Gavva, N.; Dussor, G. Meningeal transient receptor potential channel M8 activation causes cutaneous facial and hindpaw allodynia in a preclinical rodent model of headache. Cephalalgia 2016, 36, 185-193. [CrossRef]

112. Kayama, Y.; Shibata, M.; Takizawa, T.; Ibata, K.; Shimizu, T.; Ebine, T.; Toriumi, H.; Yuzaki, M.; Suzuki, N. Functional interactions between transient receptor potential M8 and transient receptor potential V1 in the trigeminal system: Relevance to migraine pathophysiology. Cephalalgia 2017. [CrossRef] 
113. Key, F.M.; Abdul-Aziz, M.A.; Mundry, R.; Peter, B.M.; Sekar, A.; D’Amato, M.; Dennis, M.Y.; Schmidt, J.M.; Andrés, A.M. Human local adaptation of the TRPM8 cold receptor along a latitudinal cline. PLoS Genet. 2018, 14, e1007298. [CrossRef]

114. Kym, P.R.; Kort, M.E.; Hutchins, C.W. Analgesic potential of TRPV1 antagonists. Biochem. Pharmacol. 2009, 78, 211-216. [CrossRef]

115. Garami, A.; Pakai, E.; McDonald, H.A.; Reilly, R.M.; Gomtsyan, A.; Corrigan, J.J.; Pinter, E.; Zhu, D.X.D.; Lehto, S.G.; Gavva, N.R.; et al. TRPV1 antagonists that cause hypothermia, instead of hyperthermia, in rodents: Compounds' pharmacological profiles, in vivo targets, thermoeffectors recruited and implications for drug development. Acta Physiol. 2018, 223, e13038. [CrossRef]

116. Arngrim, N.; Hougaard, A.; Ahmadi, K.; Vestergaard, M.B.; Schytz, H.W.; Amin, F.M.; Larsson, H.B.W.; Olesen, J.; Hoffmann, M.B.; Ashina, M. Heterogenous migraine aura symptoms correlate with visual cortex functional magnetic resonance imaging responses. Ann. Neurol. 2017, 82, 925-939. [CrossRef]

117. Hadjikhani, N.; Vincent, M. Neuroimaging clues of migraine aura. J. Headache Pain 2019, 20, 32. [CrossRef]

118. Zhang, X.; Levy, D.; Kainz, V.; Noseda, R.; Jakubowski, M.; Burstein, R. Activation of central trigeminovascular neurons by cortical spreading depression. Ann. Neurol. 2011, 69, 855-865. [CrossRef]

119. Bolay, H.; Reuter, U.; Dunn, A.K.; Huang, Z.; Boas, D.A.; Moskowitz, M.A. Intrinsic brain activity triggers trigeminal meningeal afferents in a migraine model. Nat. Med. 2002, 8, 136-142. [CrossRef]

120. Brinley, F.J.; Kandel, E.R.; Marshall, W.H. Potassium outflux from rabbit cortex during spreading depression. J. Neurophysiol. 1960, 23, 246-256. [CrossRef]

121. Gasparini, C.F.; Smith, R.A.; Griffiths, L.R. Genetic insights into migraine and glutamate: A protagonist driving the headache. J. Neurol. Sci. 2016, 367, 258-268. [CrossRef]

122. Shatillo, A.; Koroleva, K.; Giniatullina, R.; Naumenko, N.; Slastnikova, A.A.; Aliev, R.R.; Bart, G.; Atalay, M.; $\mathrm{Gu}, \mathrm{C} . ; \mathrm{Khazipov,} \mathrm{R.;} \mathrm{et} \mathrm{al.} \mathrm{Cortical} \mathrm{spreading} \mathrm{depression} \mathrm{induces} \mathrm{oxidative} \mathrm{stress} \mathrm{in} \mathrm{the} \mathrm{trigeminal} \mathrm{nociceptive}$ system. Neuroscience 2013, 253, 341-349. [CrossRef]

123. Sakaguchi, R.; Mori, Y. Transient receptor potential (TRP) channels: Biosensors for redox environmental stimuli and cellular status. Free Radic. Biol. Med. 2019. [CrossRef]

124. Melo-Carrillo, A.; Noseda, R.; Nir, R.-R.; Schain, A.J.; Stratton, J.; Strassman, A.M.; Burstein, R. Selective Inhibition of Trigeminovascular Neurons by Fremanezumab: A Humanized Monoclonal Anti-CGRP Antibody. J. Neurosci. 2017, 37, 7149-7163. [CrossRef]

125. Schain, A.J.; Melo-Carrillo, A.; Borsook, D.; Grutzendler, J.; Strassman, A.M.; Burstein, R. Activation of pial and dural macrophages and dendritic cells by cortical spreading depression. Ann. Neurol. 2018, 83, 508-521. [CrossRef]

126. Levy, D. Endogenous mechanisms underlying the activation and sensitization of meningeal nociceptors: The role of immuno-vascular interactions and cortical spreading depression. Curr. Pain Headache Rep. 2012, 16, 270-277. [CrossRef]

127. Split, W.; Szydlowska, M. Headaches in non insulin-dependent diabetes mellitus. Funct. Neurol. 1997, 12, 327-332.

128. Chai, N.C.; Scher, A.I.; Moghekar, A.; Bond, D.S.; Peterlin, B.L. Obesity and headache: Part I-a systematic review of the epidemiology of obesity and headache. Headache 2014, 54, 219-234. [CrossRef]

129. Marics, B.; Peitl, B.; Pázmándi, K.; Bácsi, A.; Németh, J.; Oszlács, O.; Jancsó, G.; Dux, M. Diet-Induced Obesity Enhances TRPV1-Mediated Neurovascular Reactions in the Dura Mater. Headache 2017, 57, 441-454. [CrossRef]

130. Marics, B.; Peitl, B.; Varga, A.; Pázmándi, K.; Bácsi, A.; Németh, J.; Szilvássy, Z.; Jancsó, G.; Dux, M. Diet-induced obesity alters dural CGRP release and potentiates TRPA1-mediated trigeminovascular responses. Cephalalgia 2017, 37, 581-591. [CrossRef]

131. Wentworth, J.M.; Naselli, G.; Brown, W.A.; Doyle, L.; Phipson, B.; Smyth, G.K.; Wabitsch, M.; O'Brien, P.E.; Harrison, L.C. Pro-inflammatory CD11c+ CD206+ adipose tissue macrophages are associated with insulin resistance in human obesity. Diabetes 2010, 59, 1648-1656. [CrossRef]

132. Calder, P.C.; Ahluwalia, N.; Brouns, F.; Buetler, T.; Clement, K.; Cunningham, K.; Esposito, K.; Jönsson, L.S.; Kolb, H.; Lansink, M.; et al. Dietary factors and low-grade inflammation in relation to overweight and obesity. Br. J. Nutr. 2011, 106, S5-S78. [CrossRef]

133. Harriott, A.M.; Gold, M.S. Electrophysiological properties of dural afferents in the absence and presence of inflammatory mediators. J. Neurophysiol. 2009, 101, 3126-3134. [CrossRef] 
134. Dux, M.; Rosta, J.; Pintér, S.; Sántha, P.; Jancsó, G. Loss of capsaicin-induced meningeal neurogenic sensory vasodilatation in diabetic rats. Neuroscience 2007, 150, 194-201. [CrossRef]

135. Troger, J.; Humpel, C.; Kremser, B.; Kralinger, M.; Teuchner, B.; Kunze, C.; Philipp, W.; Kieselbach, G. The effect of streptozotocin-induced diabetes mellitus on substance $\mathrm{P}$ and calcitonin gene-related peptide expression in the rat trigeminal ganglion. Brain Res. 1999, 842, 84-91. [CrossRef]

136. Spanou, I.; Bougea, A.; Liakakis, G.; Rizonaki, K.; Anagnostou, E.; Duntas, L.; Kararizou, E. Relationship of Migraine and Tension-Type Headache With Hypothyroidism: A Literature Review. Headache 2019, 59, 1174-1186. [CrossRef]

137. Bevilaqua Grossi, D.; Lipton, R.B.; Bigal, M.E. Temporomandibular disorders and migraine chronification. Curr. Pain Headache Rep. 2009, 13, 314-318. [CrossRef]

138. Eberhardt, M.; Neeb, L.; Vogel, E.-M.; Tiegs, G.; Reuter, U.; Messlinger, K.; Fischer, M.J.M. Glyceroltrinitrate facilitates stimulated CGRP release but not gene expression of CGRP or its receptor components in rat trigeminal ganglia. Neuropeptides 2009, 43, 483-489. [CrossRef]

139. Cheng, J.-K.; Ji, R.-R. Intracellular signaling in primary sensory neurons and persistent pain. Neurochem. Res. 2008, 33, 1970-1978. [CrossRef]

140. Kung, L.-H.; Gong, K.; Adedoyin, M.; Ng, J.; Bhargava, A.; Ohara, P.T.; Jasmin, L. Evidence for glutamate as a neuroglial transmitter within sensory ganglia. PLoS ONE 2013, 8, e68312. [CrossRef]

141. Goto, T.; Iwai, H.; Kuramoto, E.; Yamanaka, A. Neuropeptides and ATP signaling in the trigeminal ganglion. Jpn. Dent. Sci. Rev. 2017, 53, 117-124. [CrossRef]

142. Zhang, Y.; Song, N.; Liu, F.; Lin, J.; Liu, M.; Huang, C.; Liao, D.; Zhou, C.; Wang, H.; Shen, J. Activation of mitogen-activated protein kinases in satellite glial cells of the trigeminal ganglion contributes to substance P-mediated inflammatory pain. Int. J. Oral. Sci. 2019, 11, 24. [CrossRef]

143. Boye Larsen, D.; Ingemann Kristensen, G.; Panchalingam, V.; Laursen, J.C.; Nørgaard Poulsen, J.; Skallerup Andersen, M.; Kandiah, A.; Gazerani, P. Investigating the expression of metabotropic glutamate receptors in trigeminal ganglion neurons and satellite glial cells: Implications for craniofacial pain. J. Recept. Signal Transduct. Res. 2014, 34, 261-269. [CrossRef]

144. Dux, M.; Deák, É.; Tassi, N.; Sántha, P.; Jancsó, G. Endovanilloids are potential activators of the trigeminovascular nocisensor complex. J. Headache Pain 2016, 17, 53. [CrossRef]

145. Dinh, Q.T.; Cryer, A.; Dinh, S.; Trevisani, M.; Georgiewa, P.; Chung, F.; Geppetti, P.; Heppt, W.; Klapp, B.F.; Fischer, A. Protease-activated receptor 2 expression in trigeminal neurons innervating the rat nasal mucosa. Neuropeptides 2005, 39, 461-466. [CrossRef]

146. Dux, M.; Rosta, J.; Sántha, P.; Jancsó, G. Involvement of capsaicin-sensitive afferent nerves in the proteinase-activated receptor 2-mediated vasodilatation in the rat dura mater. Neuroscience 2009, 161, 887-894. [CrossRef]

147. Dai, Y.; Wang, S.; Tominaga, M.; Yamamoto, S.; Fukuoka, T.; Higashi, T.; Kobayashi, K.; Obata, K.; Yamanaka, H.; Noguchi, K. Sensitization of TRPA1 by PAR2 contributes to the sensation of inflammatory pain. J. Clin. Investig. 2007, 117, 1979-1987. [CrossRef]

148. Dux, M.; Sántha, P.; Jancsó, G. The role of chemosensitive afferent nerves and TRP ion channels in the pathomechanism of headaches. Pflug. Arch. 2012, 464, 239-248. [CrossRef]

149. Wang, R. Physiological implications of hydrogen sulfide: A whiff exploration that blossomed. Physiol. Rev. 2012, 92, 791-896. [CrossRef]

150. Kimura, H. The physiological role of hydrogen sulfide and beyond. Nitric Oxide 2014, 41, 4-10. [CrossRef]

151. Koroleva, K.; Mustafina, A.; Yakovlev, A.; Hermann, A.; Giniatullin, R.; Sitdikova, G. Receptor Mechanisms Mediating the Pro-Nociceptive Action of Hydrogen Sulfide in Rat Trigeminal Neurons and Meningeal Afferents. Front. Cell Neurosci. 2017, 11, 226. [CrossRef]

152. Eberhardt, M.; Dux, M.; Namer, B.; Miljkovic, J.; Cordasic, N.; Will, C.; Kichko, T.I.; de la Roche, J.; Fischer, M.; Suárez, S.A.; et al. H2S and NO cooperatively regulate vascular tone by activating a neuroendocrine HNO-TRPA1-CGRP signalling pathway. Nat. Commun. 2014, 5, 4381. [CrossRef]

153. Miao, X.; Meng, X.; Wu, G.; Ju, Z.; Zhang, H.-H.; Hu, S.; Xu, G.-Y. Upregulation of cystathionine- $\beta$-synthetase expression contributes to inflammatory pain in rat temporomandibular joint. Mol. Pain 2014, 10, 9. [CrossRef]

154. Hatakeyama, Y.; Takahashi, K.; Tominaga, M.; Kimura, H.; Ohta, T. Polysulfide evokes acute pain through the activation of nociceptive TRPA1 in mouse sensory neurons. Mol. Pain 2015, 11, 24. [CrossRef] 
155. Kimura, $\mathrm{H}$. Hydrogen polysulfide ( $\mathrm{H} 2 \mathrm{~S} \mathrm{n})$ signaling along with hydrogen sulfide (H2S) and nitric oxide (NO). J. Neural Transm. 2016, 123, 1235-1245. [CrossRef]

156. Fukuto, J.M.; Switzer, C.H.; Miranda, K.M.; Wink, D.A. Nitroxyl (HNO): Chemistry, biochemistry, and pharmacology. Annu. Rev. Pharmacol. Toxicol. 2005, 45, 335-355. [CrossRef]

157. Dux, M.; Will, C.; Vogler, B.; Filipovic, M.R.; Messlinger, K. Meningeal blood flow is controlled by H2 S-NO crosstalk activating a HNO-TRPA1-CGRP signalling pathway. Br. J. Pharmacol. 2016, 173, 431-445. [CrossRef]

158. Diener, H.-C.; Holle, D.; Solbach, K.; Gaul, C. Medication-overuse headache: Risk factors, pathophysiology and management. Nat. Rev. Neurol. 2016, 12, 575-583. [CrossRef]

159. Masaaki, I.; Hideyo, K.; Hirotaka, K.; Masakazu, I. Lack of Association between TRP Gene Polymorphisms and Complication of Medication Overuse Headache in Migraine Patients. J. Med. Clin. Res. Rev. 2018, 2, 1-5.

160. Van Hoogstraten, W.S.; MaassenVanDenBrink, A. The need for new acutely acting antimigraine drugs: Moving safely outside acute medication overuse. J. Headache Pain 2019, 20, 54. [CrossRef]

161. Srikiatkhachorn, A.; le Grand, S.M.; Supornsilpchai, W.; Storer, R.J. Pathophysiology of medication overuse headache - an update. Headache 2014, 54, 204-210. [CrossRef]

162. Carvalho, C.; Santos, R.X.; Cardoso, S.; Correia, S.; Oliveira, P.J.; Santos, M.S.; Moreira, P.I. Doxorubicin: The good, the bad and the ugly effect. Curr. Med. Chem. 2009, 16, 3267-3285. [CrossRef]

163. Kondo, A.; Ohnishi, A.; Nagara, H.; Tateishi, J. Neurotoxicity in primary sensory neurons of adriamycin administered through retrograde axoplasmic transport in rats. Neuropathol. Appl. Neurobiol. 1987, 13, 177-192. [CrossRef]

164. Katona, M.; Boros, K.; Sántha, P.; Ferdinandy, P.; Dux, M.; Jancsó, G. Selective sensory denervation by capsaicin aggravates adriamycin-induced cardiomyopathy in rats. Naunyn Schmiedebergs Arch. Pharmacol. 2004, 370, 436-443. [CrossRef]

165. Deák, É.; Rosta, J.; Boros, K.; Kis, G.; Sántha, P.; Messlinger, K.; Jancsó, G.; Dux, M. Chronic adriamycin treatment impairs CGRP-mediated functions of meningeal sensory nerves. Neuropeptides 2018, 69, 46-52. [CrossRef]

166. Edvinsson, L.; Warfvinge, K. Recognizing the role of CGRP and CGRP receptors in migraine and its treatment. Cephalalgia 2017, 366-373. [CrossRef]

167. Eftekhari, S.; Salvatore, C.A.; Johansson, S.; Chen, T.-B.; Zeng, Z.; Edvinsson, L. Localization of CGRP, CGRP receptor, PACAP and glutamate in trigeminal ganglion. Relation to the blood-brain barrier. Brain Res. 2015, 1600, 93-109. [CrossRef]

168. Edvinsson, L.; Tajti, J.; Szalárdy, L.; Vécsei, L. PACAP and its role in primary headaches. J. Headache Pain 2018, 19, 21. [CrossRef]

169. Benemei, S.; Cortese, F.; Labastida-Ramírez, A.; Marchese, F.; Pellesi, L.; Romoli, M.; Vollesen, A.L.; Lampl, C.; Ashina, M. School of Advanced Studies of the European Headache Federation (EHF-SAS) Triptans and CGRP blockade-impact on the cranial vasculature. J. Headache Pain 2017, 18, 103. [CrossRef]

170. Lambert, G.A.; Davis, J.B.; Appleby, J.M.; Chizh, B.A.; Hoskin, K.L.; Zagami, A.S. The effects of the TRPV1 receptor antagonist SB-705498 on trigeminovascular sensitisation and neurotransmission. Naunyn Schmiedebergs Arch. Pharmacol. 2009, 380, 311-325. [CrossRef]

171. Meents, J.E.; Hoffmann, J.; Chaplan, S.R.; Neeb, L.; Schuh-Hofer, S.; Wickenden, A.; Reuter, U. Two TRPV1 receptor antagonists are effective in two different experimental models of migraine. J. Headache Pain 2015, 16, 57. [CrossRef]

172. Summ, O.; Holland, P.R.; Akerman, S.; Goadsby, P.J. TRPV1 receptor blockade is ineffective in different in vivo models of migraine. Cephalalgia 2011, 31, 172-180. [CrossRef]

173. Edelmayer, R.M.; Le, L.N.; Yan, J.; Wei, X.; Nassini, R.; Materazzi, S.; Preti, D.; Appendino, G.; Geppetti, P.; Dodick, D.W.; et al. Activation of TRPA1 on dural afferents: A potential mechanism of headache pain. Pain 2012, 153, 1949-1958. [CrossRef]

174. Materazzi, S.; Benemei, S.; Fusi, C.; Gualdani, R.; De Siena, G.; Vastani, N.; Andersson, D.A.; Trevisan, G.; Moncelli, M.R.; Wei, X.; et al. Parthenolide inhibits nociception and neurogenic vasodilatation in the trigeminovascular system by targeting the TRPA1 channel. Pain 2013, 154, 2750-2758. [CrossRef]

175. Leamy, A.W.; Shukla, P.; McAlexander, M.A.; Carr, M.J.; Ghatta, S. Curcumin ((E,E)-1,7-bis(4-hydroxy-3-methoxyphenyl)-1,6-heptadiene-3,5-dione) activates and desensitizes the nociceptor ion channel TRPA1. Neurosci. Lett. 2011, 503, 157-162. [CrossRef] 
176. Wang, S.; Yamamoto, S.; Kogure, Y.; Zhang, W.; Noguchi, K.; Dai, Y. Partial Activation and Inhibition of TRPV1 Channels by Evodiamine and Rutaecarpine, Two Major Components of the Fruits of Evodia rutaecarpa. J. Nat. Prod. 2016, 79, 1225-1230. [CrossRef]

177. Lipton, R.B.; Göbel, H.; Einhäupl, K.M.; Wilks, K.; Mauskop, A. Petasites hybridus root (butterbur) is an effective preventive treatment for migraine. Neurology 2004, 63, 2240-2244. [CrossRef]

178. Benemei, S.; De Logu, F.; Li Puma, S.; Marone, I.M.; Coppi, E.; Ugolini, F.; Liedtke, W.; Pollastro, F.; Appendino, G.; Geppetti, P.; et al. The anti-migraine component of butterbur extracts, isopetasin, desensitizes peptidergic nociceptors by acting on TRPA1 cation channel. Br. J. Pharmacol. 2017, 174, 2897-2911. [CrossRef] 